\title{
Synthesis and Anti-Tumor Activity of Oleanolic Acid
}

\author{
Derivatives \\ Zhenyu Kuai, Lei Li, Shenwen Zhan, Chunlin Li, Yuwei Zhao, Hongrong Chen and \\ Yanqiu Meng * \\ Department of Pharmaceutical Engineering, Shenyang University of Chemical \\ Technology, Shenyang 110142, China
}

\begin{abstract}
With the computer drug-aided design and the key amino acid residue fragment of the target protein analyzed on the basis of simulated docking of Survivin and known active small molecules, the active groups capable of binding to the critical sites were determined. After the natural product Oleanolic acid was used as lead compound, then the active groups were introduced on the ring of A, next the carboxyl group at the C-28 position was modified by esterification or amidation, twenty new Oleanolic acid derivatives had been designed and synthesized. SKOV3 and BGC-823 cells were used to screen the antitumor activity in vitro through the standard MTT method. Among the selection, compounds $\mathbf{I I}_{\mathbf{3}} 、 \mathbf{I I I}_{\mathbf{5}}$ and $\mathrm{IV}_{\mathbf{4}}$ exhibited more potent cytotoxicity than positive drugs.
\end{abstract}

Keywords: oleanolic acid derivatives; synthesis; anti-tumor activity; molecular docking

\section{Introduction}

Oleanolic acid (OA) is a pentacyclic triterpenoid compound, which is widely present in plants in the form of dissociation or in combination with sugars ${ }^{[1]}$. An active ingredients, mainly separated from Prunella vulgaris, Honeysuckle, Olive, Forsythia, Aloe Vera and Ligustrum lucidum and other plants ${ }^{[2]}$, oleanolic acid has a variety of important pharmacological functions, such as anti-virus [3-5], anti-diabetic and hypoglycemic, anti-HBV, and anti-tumor. Our research group has carried out the antitumor research in pentacyclic triterpenoid analogues since 2000, which mainly focuses on the extensive structural modification of inactylactic acid, ursolic acid, asiatic acid and in vitro antitumor activity evaluation ${ }^{[6-9]}$. In addition, some progress has been made in guiding the structural transformation of oleanolic acid, ursolic acid and asiatic acid on the basis of the combination of computer-aided design analogue analyte and protein target ${ }^{[10-11]}$.

Survivin, a member of apoptotic proteins family, is considered as an important target for anticancer therapy ${ }^{[12]}$ due to its function in cell division and suppression. Oleanolic acid (OA) and 5-FU, combined together, impact significantly the human pancreatic cell (Panc-28) apoptosis through inhibiting Survivin ${ }^{[13]}$. By improving the proapoptotic protein Bax and changing the balance of Bcl-2/Bax, OA significantly reduce the expression of anti-tumor apoptotic protein Survivin ${ }^{[14]}$. YM155 has a naphthoquinolidazole structure that inhibits the transformation of Survivin gene through inhibiting the promoter activity ${ }^{[15-16]}$. And it has been in the clinical stage I, II study. SC144, with structure of quinolide hydrazine, can inhibit the IL-6/gp130/Stat3 
signal axis, bind gp130, induce gp130 phosphorylation and de-glycosylation, prevent Stat3 phosphorylation and nuclear migration, and ultimately inhibit the downstream expression of Survivin ${ }^{[17]}$. It is the first oral active inhibitor of gp130. After combining the three-dimensional crystal structure (PDB: 3UIH) of Survivin protein in PDB database, and analyzing the interaction between known Survivin small molecule inhibitor and target enzyme by molecular simulation docking method, and studding the key amino acid residue fragment, we determine the active site that binds to the critical site, which is shown on Figure 1. And the active group fragments in the partial inhibitor structure were introduced into the tricyclic triterpenoid matrix and the main transformation concentrated in the A-ring parallel nitrogen-containing heterocyclic ring, have shown in Figure 2. Twenty new oleanolic acid analogs were designed and synthesized and tested for in vitro activity.

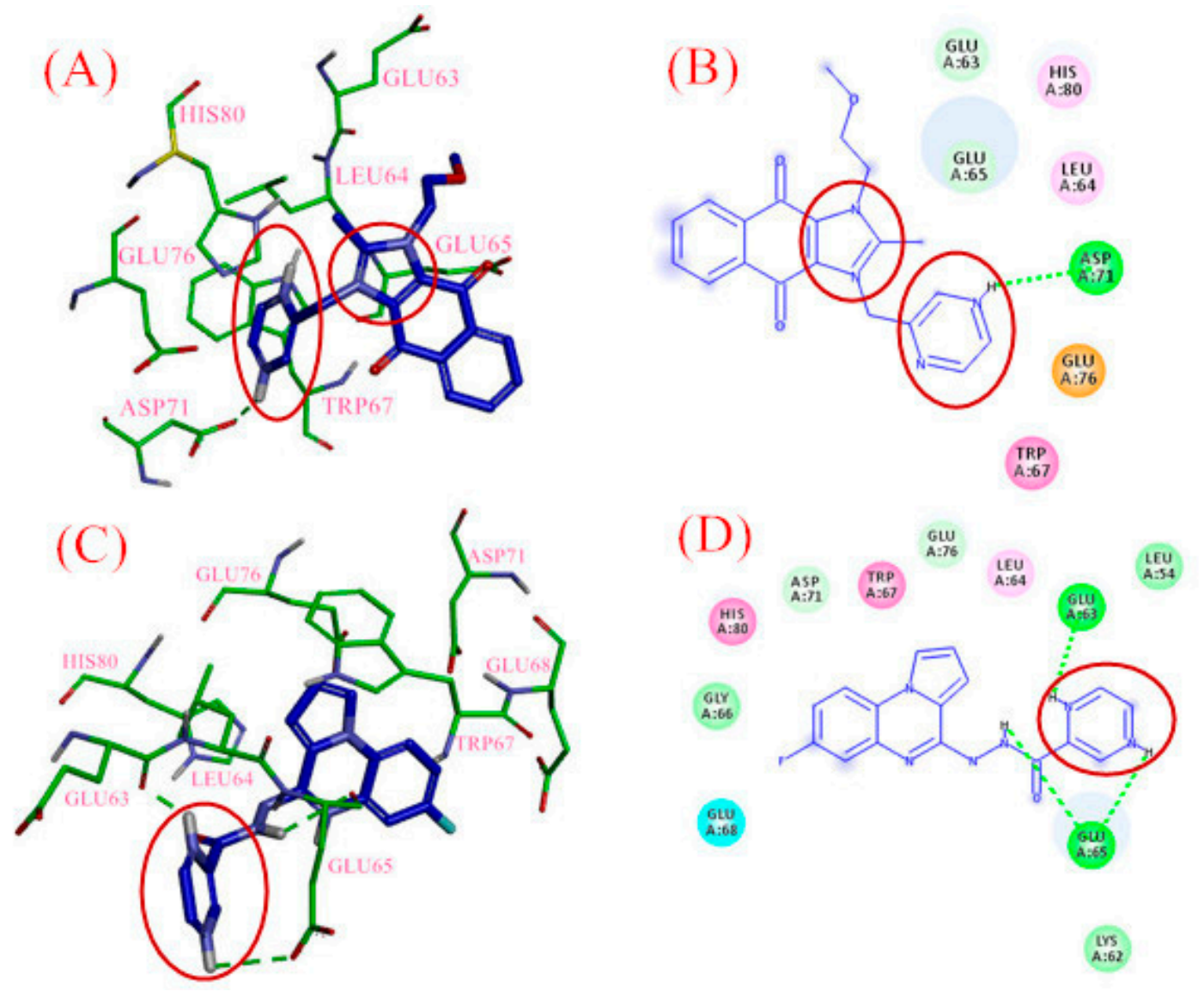

Figure1. Analysis of the Interaction of YM155 and SC144 with 3UIH,the key amino acids:ASP71,GLU63,GLU65 


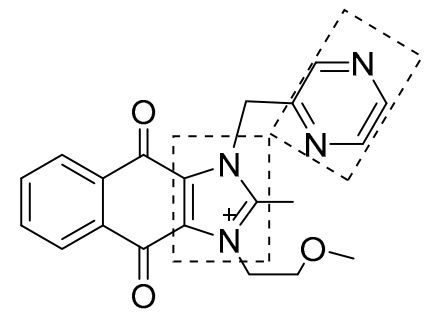

YM155<smiles></smiles>

SC144

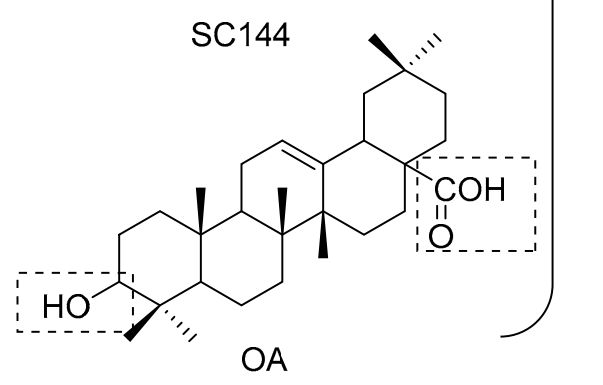

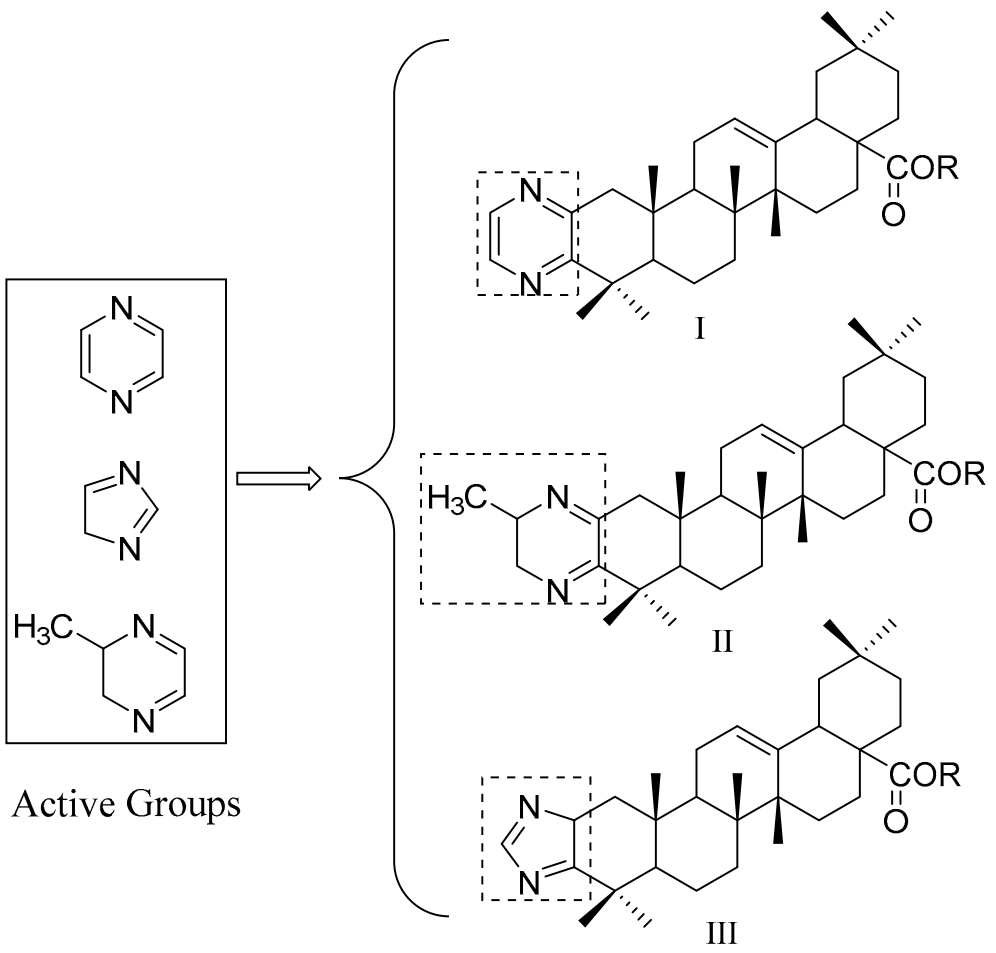

Figure2. The analytical active groups introduce oleanolic acid and design new derivatives

In this paper, we put together the structural modification of pentacyclic triterpene compounds suggested by Meng's study team, the antitumor compounds which have entered clinical research (Figure 1), and the computer simulation to analyze the structure of the key active groups (Figure 2). We introduce these groups in A ring of oleanolic acid. Through computer molecular docking simulation analysis, the combination mode of $\mathbf{I I}_{3} 、 \mathrm{III}_{5}$ and $\mathrm{IV}_{\mathbf{4}}$ with Survivin targeting protein displays a strong combining ability. The antitumor activities have been tested in vitro by MTT. The results showed that compounds $\mathrm{III}_{5}$ and $\mathrm{IV}_{4}$ have more outstanding antitumor activities on SKOV3 and BGC-823 cells than Adriamycin.

\section{Results and discussion}

\subsection{Chemical Synthesis}

A total of 20 compounds were designed and synthesized from four categories with OA as original material. The target compound route was shown in Scheme 1. First, the Jones reagent was used to oxidize the oleanolic acid at the 3-position hydroxyl group to the ketone to obtain OA-1. On this basis, the 28-carboxyl group was esterified or amidized to obtain the compound OA-2 and OA-6. Then they react with (T-BuOK) respectively, result in compounds OA-3 and OA-7 under basic 
conditions at $50^{\circ} \mathrm{C}$, which are further synthesized to result in olean-2-ene-[2,3-b] pyrazin-12-ene-28-carboxylic acid ester compounds I 1 to I4, 5'-methyl-olean-2-ene[2,3-b] pyrazine-12-ene-28-oic acid ester compounds II $_{1}$ to II $_{5}$, and 5'-methyl-olean-2ene-[2,3-b] pyrazine-12-ene-28-carboxylic acid amide compounds $\mathrm{IV}_{1}$ to $\mathrm{IV}_{5}$. In addition, OA-2 reacted with hydrazine hydrate to gain OA-5, which, after cyclization, forms olean-2-ene- [2,3-b] imidazole-12-ene-28-oic acid ester $\mathrm{III}_{1}$ to $\mathrm{III}_{5}$.

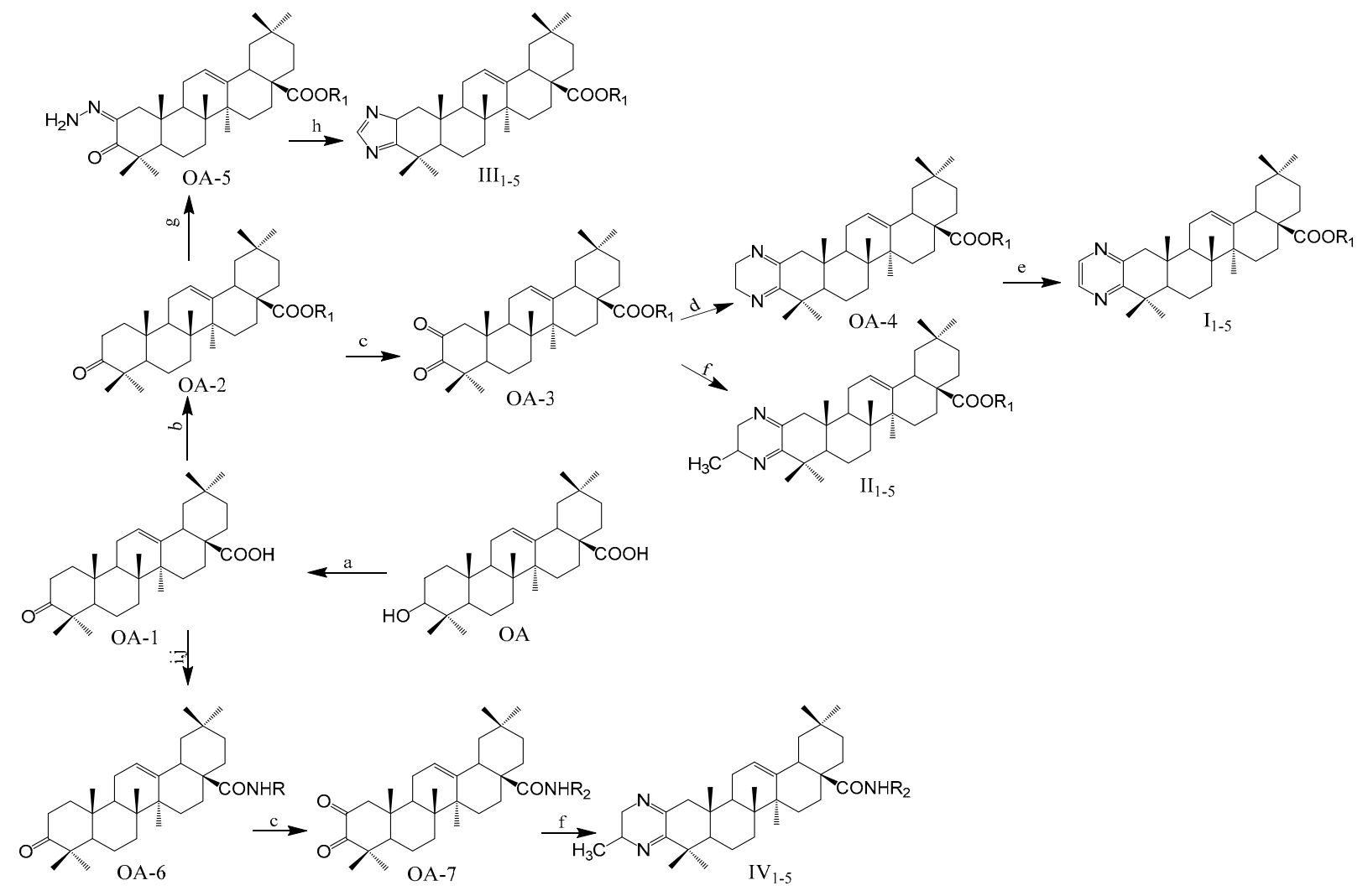

\begin{tabular}{cccccccc} 
Comp. & $\mathrm{R}_{1}$ & Comp. & $\mathrm{R}_{1}$ & Comp. & $\mathrm{R}_{1}$ & Comp. \\
\hline $\mathrm{I}_{1}$ & $-\mathrm{C}_{2} \mathrm{H}_{5}$ & $\mathrm{II}_{1}$ & $-\mathrm{C}_{2} \mathrm{H}_{5}$ & $\mathrm{III}_{1}$ & $-\mathrm{C}_{2} \mathrm{H}_{5}$ & $\mathrm{IV}_{1}$ \\
$\mathrm{I}_{2}$ & $-\mathrm{C}_{3} \mathrm{H}_{7}$ & $\mathrm{II}_{2}$ & $-\mathrm{C}_{3} \mathrm{H}_{7}$ & $\mathrm{III}_{2}$ & $-\mathrm{C}_{3} \mathrm{H}_{7}$ & $\mathrm{IV}_{2}$ \\
$\mathrm{I}_{3}$ & $-\mathrm{C}_{4} \mathrm{H}_{9}$ & $\mathrm{II}_{3}$ & $-\mathrm{C}_{4} \mathrm{H}_{9}$ & $\mathrm{III}_{3}$ & $-\mathrm{C}_{4} \mathrm{H}_{9}$ & $\mathrm{IV}_{3}$ \\
$\mathrm{I}_{4}$ & $-\mathrm{C}_{5} \mathrm{H}_{11}$ & $\mathrm{II}_{4}$ & $-\mathrm{C}_{5} \mathrm{H}_{11}$ & $\mathrm{III}_{4}$ & $-\mathrm{C}_{5} \mathrm{H}_{11}$ & $\mathrm{IV}_{4}$ \\
$\mathrm{I}_{5}$ & $-\mathrm{C}_{6} \mathrm{H}_{13}$ & $\mathrm{II}_{5}$ & $-\mathrm{C}_{6} \mathrm{H}_{13}$ & $\mathrm{III}_{5}$ & $-\mathrm{C}_{6} \mathrm{H}_{13}$ & $\mathrm{IV}_{5}$
\end{tabular}

Reagents and conditions:(a)Jones, acetone,r.t., $1 \mathrm{~h}$;(b)RBr, $\mathrm{K}_{2} \mathrm{CO}_{3}$, DMF;(c)t-BuOH,t-BuOK,reflux, $5 \mathrm{~h}, 50^{\circ} \mathrm{C}$;

(d)EtOH, $\mathrm{C}_{2} \mathrm{H}_{8} \mathrm{~N}_{2}$, reflux,6h;(e)KOH, $\mathrm{MnO}_{2}$, EtOH,r.t.;(f)EtOH, $\mathrm{C}_{3} \mathrm{H}_{11} \mathrm{~N}_{2}$, reflux,6h;(g) $\mathrm{N}_{2} \mathrm{H}_{4} \cdot \mathrm{H}_{2} \mathrm{O}$, EtOH,reflux, 1 h; (h)HCOOH,reflux,3h;(i)DCM,(COCl) 2 ,DMF,r.t.4h;(j)amins,DCM,r.t.24h;

Scheme1 Synthetic routes of target compounds.

\subsection{Biological evaluation}

The inhibitory activity of target compounds $\mathbf{I}_{1-5}, \mathbf{I I}_{1-5}, \mathbf{I I I}_{1-5}, \mathrm{IV}_{\mathbf{1 - 5}}$ on SKOV3 and BGC-823 cells was tested in vitro by the MTT method, meanwhile gefitinib and 5-FU acted as the positive control. As shown in Table 1, all the tested compounds indicated 
some inhibitory effect on SKOV3 and BGC-823 cells. Among the compounds, $\mathbf{I I}_{3}$ 、 III 5 and $\mathrm{IV}_{4}$ showed excellent inhibitory effects on SKOV3 cells $\left(\mathrm{IC}_{50}=8.3 \mu \mathrm{M}, \mathrm{IC}_{50}\right.$ $\left.=7.8 \mu \mathrm{M}, \mathrm{IC}_{50}=8.0 \mu \mathrm{M}\right)$ and BGC-823 cells $\left(\mathrm{IC}_{50}=6.3 \mu \mathrm{M}, \mathrm{IC}_{50}=4.3 \mu \mathrm{M}, \mathrm{IC}_{50}=7.9 \mu \mathrm{M}\right)$, which manifested a 7.1,10.4 and 5.6-fold to enhance the anticancer activity compared to that of Adriamycin, respectively.

Through the analysis of tumor cells morphological variation, we found that the distribution of the diamond BGC-823 cells showed fragmental, cavitation, and apopt osis gradually after 72 hours. Whereas, the blank control group cell lines had been in malignant proliferation state. By contrast, we can conclude that compounds $\mathbf{I I I}_{5}$ and $\mathrm{IV}_{4}$ have significant inhibitory activity on SKOV3 and BGC-823 cells. The results have shown in Figure 3 and Figure 4.
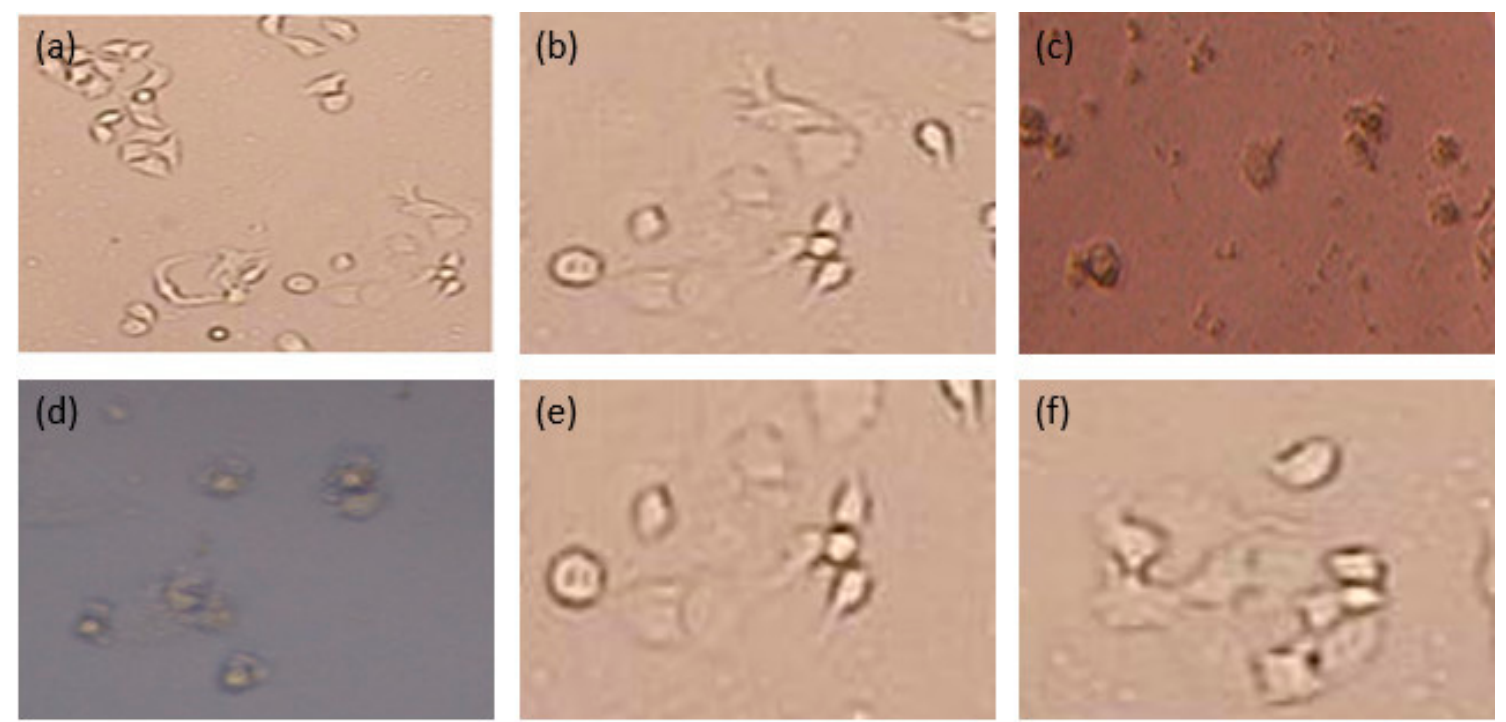

Figure 3. Morphological changes of SKOV3 cells induced by different compounds, $72 \mathrm{~h}$

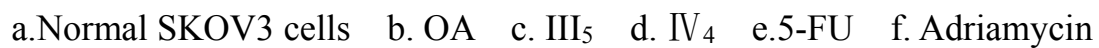
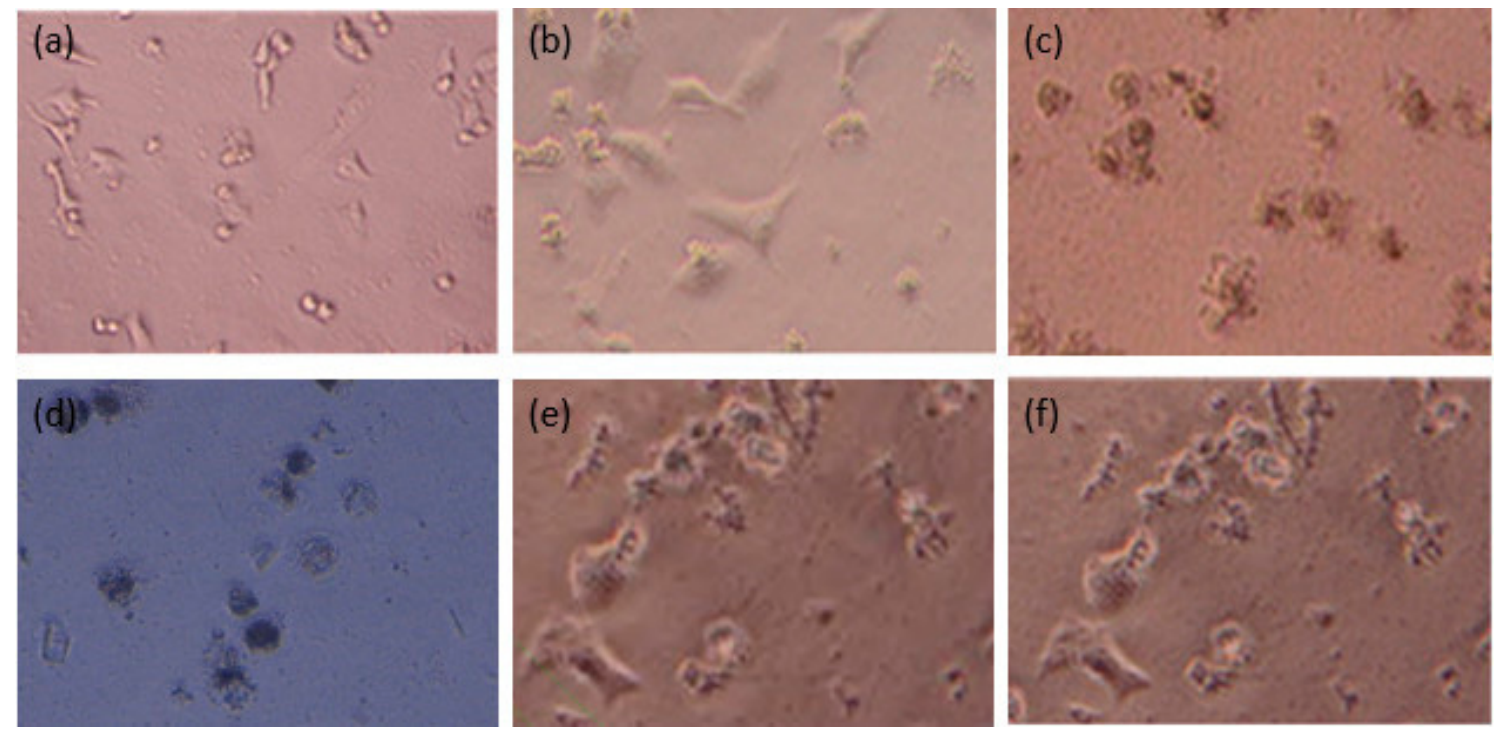

Figure 4. Morphological changes of BGC-823 cells induced by different compounds, $72 \mathrm{~h}$
a.Normal BGC-823 cells
b. $\mathrm{OA}$
c. $\mathrm{III}_{5}$
d. $\mathrm{IV}_{4} \quad$ e.5-FU
f. Adriamycin 
Table 1. Antitumor activity of the target compounds on SKOV3 and BGC-823 cell lines.

\begin{tabular}{|c|c|c|c|c|}
\hline \multirow{2}{*}{ Compd. } & \multicolumn{2}{|c|}{ Inhibition Rate (\%) ${ }^{\text {a }}$} & \multicolumn{2}{|c|}{$\operatorname{IC} 50(\mu \mathrm{M})^{\mathrm{b}}$} \\
\hline & SKOV3 & BGC-823 & SKOV3 & BGC-823 \\
\hline OA & 12.7 & 10.3 & $>50$ & $>50$ \\
\hline $\mathbf{I}_{1}$ & 29.5 & 30.6 & $>50$ & $>50$ \\
\hline $\mathbf{I}_{2}$ & 35.7 & 33.2 & 35.3 & 36.7 \\
\hline $\mathbf{I}_{3}$ & 39.2 & 30.3 & 30.9 & 40.1 \\
\hline $\mathbf{I}_{4}$ & 32.1 & 26.5 & $>50$ & $>50$ \\
\hline $\mathbf{I}_{5}$ & 41.5 & 43.1 & 27.5 & 25.3 \\
\hline $\mathbf{I I}_{1}$ & 36.2 & 37.3 & 32.6 & $>50$ \\
\hline $\mathbf{I I}_{2}$ & 27.9 & 26.7 & $>50$ & $>50$ \\
\hline $\mathrm{II}_{3}$ & 57.3 & 59.6 & 8.3 & 6.2 \\
\hline $\mathrm{II}_{4}$ & 39.1 & 38.4 & 30.2 & 33.6 \\
\hline $\mathrm{II}_{5}$ & 35.6 & 37.2 & 40.3 & $>50$ \\
\hline III $_{1}$ & 42.6 & 44.3 & 26.7 & 21.3 \\
\hline $\mathrm{III}_{2}$ & 43.5 & 41.6 & 25.6 & 28.3 \\
\hline $\mathrm{III}_{3}$ & 56.3 & 49.2 & 10.2 & 17.6 \\
\hline $\mathrm{III}_{4}$ & 38.9 & 36.2 & 32.6 & 35.7 \\
\hline $\mathrm{III}_{5}$ & 60.9 & 63.4 & 7.8 & 4.3 \\
\hline $\mathrm{IV}_{1}$ & 57.8 & 55.1 & 8.0 & 10.1 \\
\hline $\mathrm{IV}_{2}$ & 37.8 & 35.6 & 42.6 & $>50$ \\
\hline $\mathrm{IV}_{3}$ & 33.4 & 31.5 & $>50$ & $>50$ \\
\hline $\mathrm{IV}_{4}$ & 62.1 & 58.3 & 5.3 & 7.9 \\
\hline $\mathrm{IV}_{5}$ & 40.1 & 38.5 & 29.7 & 33.6 \\
\hline 5-FU & 42.3 & 45.6 & 26.3 & 21.1 \\
\hline Adriamycin & 46.8 & 37.9 & 30.6 & 44.6 \\
\hline
\end{tabular}

\subsection{Molecular docking}

Oleanolic acid derivatives $\mathbf{I}_{\mathbf{1}-5}, \mathbf{I I}_{\mathbf{1}-5}, \mathbf{I I I}_{\mathbf{1 - 5}}, \mathrm{IV}_{\mathbf{1 - 5}}$ have the combined affinity with Survivin protein (PDB code: 3UIH). Molegro Virtual Docker (MVD) is able to predict how protein interacts with macromolecular ligands and its interaction energy. The connection between 3UIH and molecules was assessed by MVD. Scores are expressed as binding free energy $\left(\mathrm{E}_{\text {score }} \mathrm{kcal} / \mathrm{mol}\right)$. Using MVD 6.0, the binding scores showed that compound $\mathbf{I I}_{3}$ : -76.432 , compound $\mathbf{I I I}_{5}$ : -86.021 , compound $\mathrm{IV}_{4}:-78.851$, in comparison with protein's small molecule ligands (-75.542).The lower the energy score is, the stronger the binding affinity becomes. Through intuiting analysis of the combination of compounds and targets by the Discovery Studio 4.0, we found that some 
compounds interacted with Survivin protein and closely connected with the surrounding amino acids. Based on Figure 5, Figure 6 and Figure 7, compounds $\mathbf{I I}_{\mathbf{3}}$, $\mathrm{III}_{5}$ and $\mathrm{IV}_{4}$ were firmly fixed in the hydrophobic pocket and they interacted with key amino acids through hydrophobic bond and H-bond. Key energy could not be measured in the process of the molecular docking. MolDock score of all compounds are shown in Table 2. In this step, we cooperated with Shenyang Pharmaceutical University.
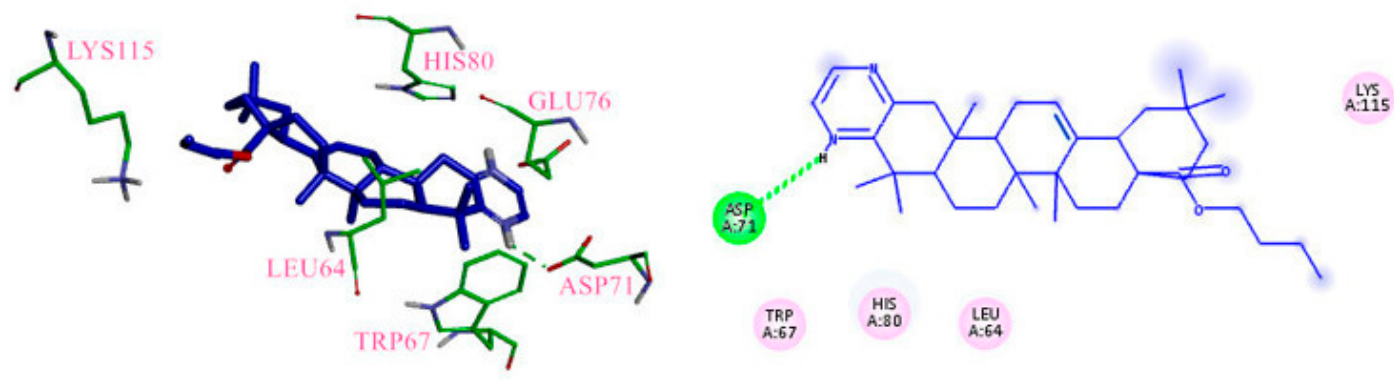

Figure 5. Binding of compound $\mathbf{I}_{3}$ to the active site of Survivin, it exhibited 1 H-bond with ASP71, the hydrogen bonds formed colored in green.
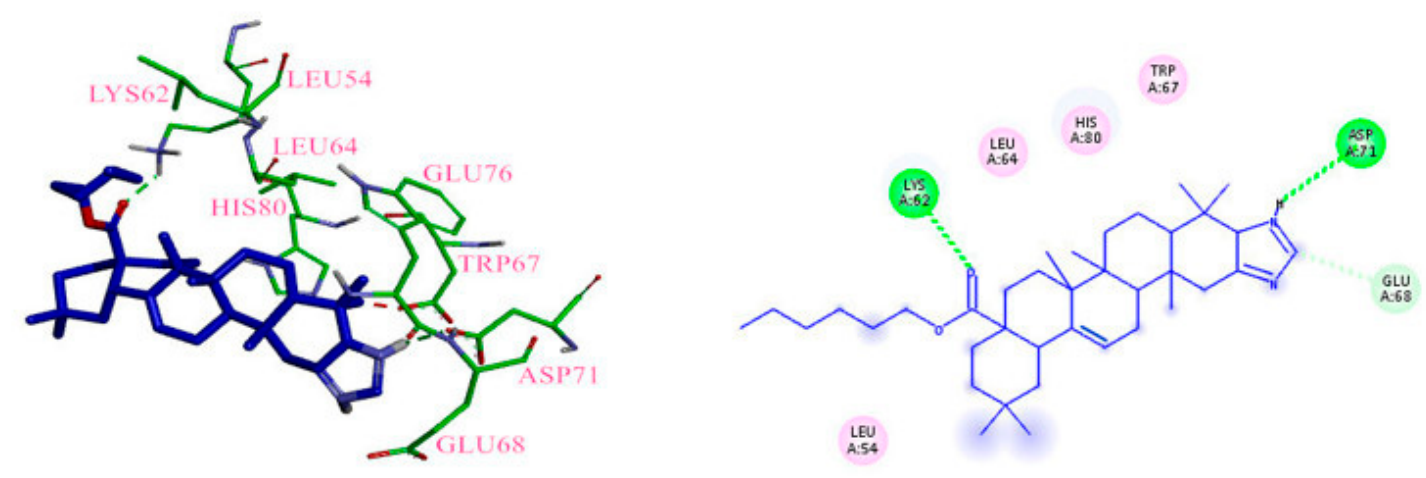

Figure 6. Binding of compound III $_{5}$ to the active site of Survivin, it exhibited 2 H-bonds with LYS62 and ASP71, the hydrogen bonds formed colored in green.
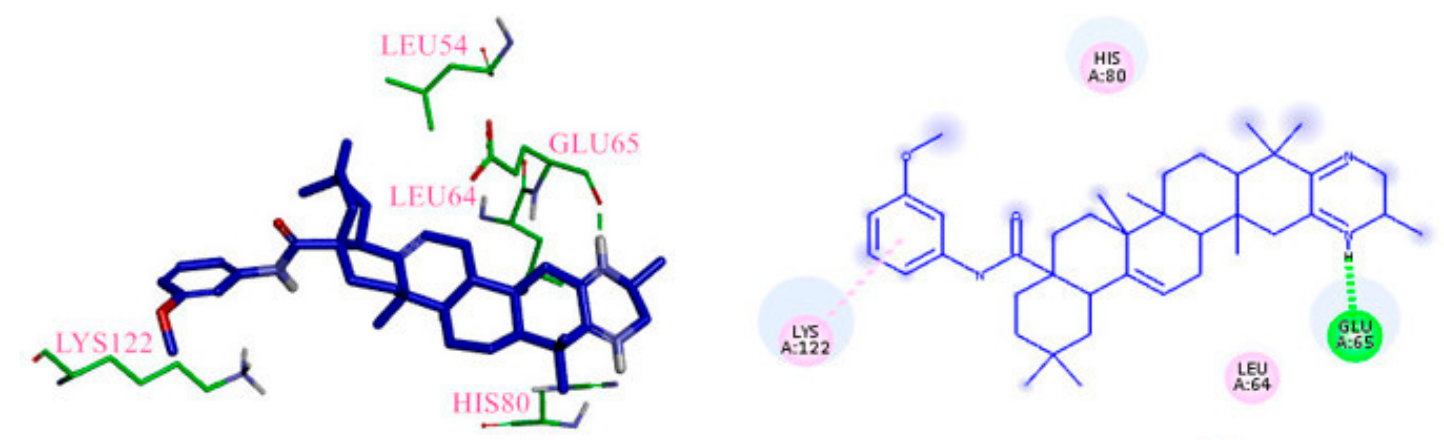

LEU

Figure 7. Binding of compound $\mathrm{IV}_{4}$ to the active site of Survivin, it exhibited $1 \mathrm{H}$-bonds with GLU65, the hydrogen bonds formed colored in green. 
Table 2. Comparison of energy scores for different compounds with Survivin protein.

\begin{tabular}{cccc}
\hline Compd. & MolDock Score & Compd. & MolDock Score \\
\hline $\mathbf{I}_{\mathbf{1}}$ & -67.387 & $\mathbf{I I}_{\mathbf{1}}$ & -74.600 \\
$\mathbf{I}_{\mathbf{2}}$ & -69.850 & $\mathbf{I I}_{\mathbf{2}}$ & -71.915 \\
$\mathbf{I}_{\mathbf{3}}$ & -72.289 & $\mathbf{I I I}_{\mathbf{3}}$ & -76.533 \\
$\mathbf{I}_{\mathbf{4}}$ & -65.424 & $\mathbf{I I I}_{\mathbf{4}}$ & -69.951 \\
$\mathbf{I}_{\mathbf{5}}$ & -73.277 & $\mathbf{I I I}_{\mathbf{5}}$ & -90.022 \\
$\mathbf{I}_{\mathbf{1}}$ & -68.272 & $\mathrm{IV}_{\mathbf{1}}$ & -74.103 \\
$\mathbf{I I}_{\mathbf{2}}$ & -64.290 & $\mathrm{IV}_{\mathbf{2}}$ & -78.620 \\
$\mathbf{I I}_{\mathbf{3}}$ & -80.432 & $\mathrm{IV}_{\mathbf{3}}$ & -60.720 \\
$\mathbf{I I}_{\mathbf{4}}$ & -69.015 & $\mathrm{IV}_{\mathbf{4}}$ & -80.851 \\
$\mathbf{I I}_{\mathbf{5}}$ & -68.397 & $\mathrm{IV}_{\mathbf{5}}$ & -71.225 \\
Molecule & -75.542 & & \\
\hline
\end{tabular}

\section{Conclusions}

In summary, four new series of OA derivatives were designed and synthesized. Their antitumor activities on SKOV3 and BGC-823 cell lines were evaluated. All the tested compounds showed some anticancer activity against SKOV3 and BGC-823 cell lines. Molecular docking studies demonstrated that twenty OA derivatives were obtained through structural optimization of the lead compound(OA) and they docked into Survivin protein-tyrosine kinase. Molegro Virtual Docker (MVD) was able to tell if there was good binding affinity of the synthesized all compounds with Survivin protein. Specifically, compounds $\mathbf{I I}_{\mathbf{3}} 、 \mathbf{I I I}_{\mathbf{5}}$ and $\mathrm{IV}_{\mathbf{4}}$ exhibited outstanding inhibitory activities on SKOV3 cells ( $\left.\mathrm{IC}_{50}=8.3 \mu \mathrm{M}, \mathrm{IC}_{50}=7.8 \mu \mathrm{M}, \mathrm{IC}_{50}=8.0 \mu \mathrm{M}\right)$ and BGC-823 cells $\left(\mathrm{IC}_{50}=6.3 \mu \mathrm{M}, \mathrm{IC}_{50}=4.3 \mu \mathrm{M}, \mathrm{IC}_{50}=7.9 \mu \mathrm{M}\right)$. They showed a 7.1,10.4 and 5.6-fold enhanced anticancer activity, compared with the positive control Adriamycin.As the ester chain of OA increases, the anticancer activity increases. The structure-activity relationships of newly synthesized compounds have shown in Figure 8. Our data indicated that proper structural modification at A ring and C-28 position of $\mathrm{OA}$ is necessary to enhance the anticancer activity of Oleanolic acid. 


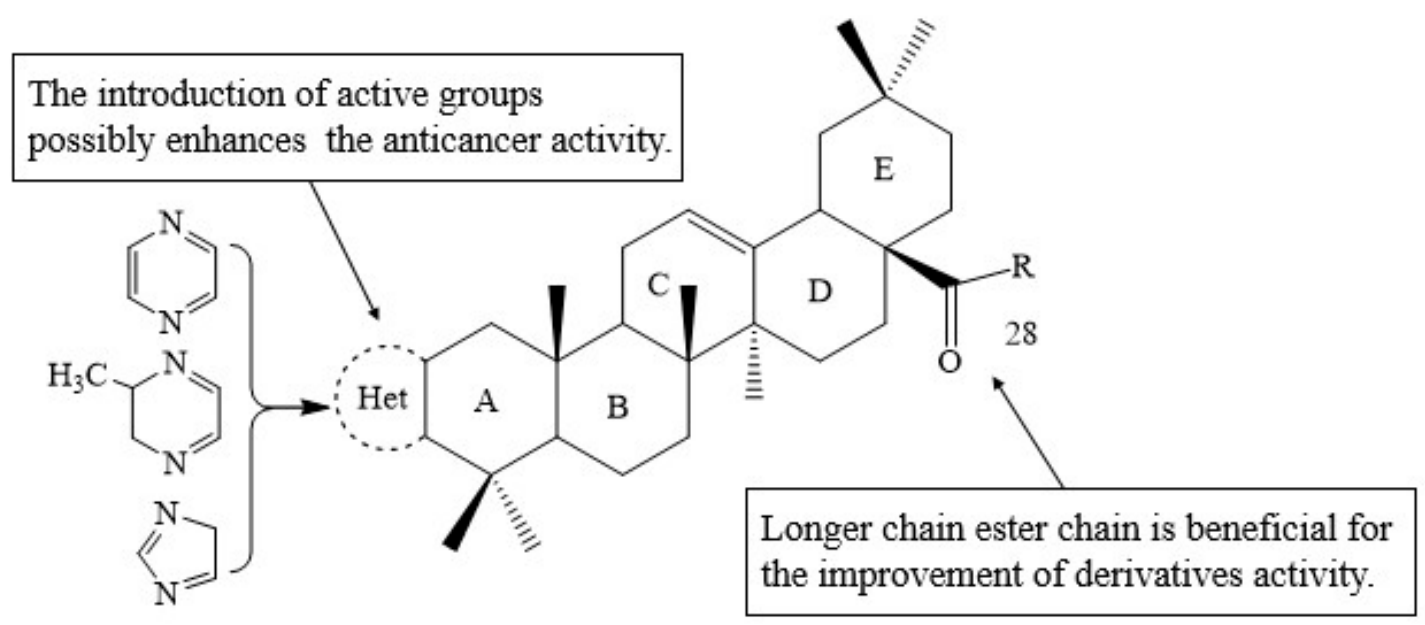

Figure 8. Summarized structure-activity relationships of novel compounds with regard to cancer inhibition.

\section{Experimental}

\subsection{General experimental procedures}

The melting points were determined on a Büchi B-540 melting point apparatus produced by Broker Corporation (Flawil, Switzerland) and are uncorrected. ${ }^{1} \mathrm{HNMR}$ spectra were recorded on Bruker a ARX-300 $\mathrm{MHz}$ spectrometers from Bruker Corporation (Ettlingen, Germany) and the solvent is $\mathrm{CDCl}_{3}$, using trimethylsilane as an internal standard. ESI-MS were measured on a Thermo-Finnigan LCQ equipment from Thermo Finnigan (San Francisco, CA, USA). Thin-layer chromatography (TLC) ware carried out with GF 254, column chromatograph with silica gel (200-300 mesh) obtained from Qing-dao Marine Chemical Factory (Qingdao, China). The reagents were all of analytical grade or chemically pure.

\subsection{Preparation of the compounds}

\subsubsection{3-Oxo-olean-12-ene-28-oic acid (OA-1)}

OA $(0.500 \mathrm{~g})$ was dissolved in $50 \mathrm{~mL}$ of acetone, and allowed to react with the newly prepared Jones' reagent $(0.64 \mathrm{~mL})$ under ice bath. The end of the reaction was detected by TLC. $15 \mathrm{~mL}$ of isopropanol was added to quench its oxidizing property and stirred at room temperature for $30 \mathrm{~min}$. A small amount of saturated sodium chloride solution and moderate ethyl acetate were added to the reaction mixture to extract for three times. The organic layer was dried with anhydrous magnesium sulfate for $4 \mathrm{~h}$. The crude product was purified by silica gel column chromatography (eluent: petroleum ether/ethyl acetate $=12 / 1(\mathrm{~V} / \mathrm{V}))$. Then, the solvent were removed to give a powder OA1 , with a yield of $98.0 \%$. m.p. $200.4 \sim 202.1^{\circ} \mathrm{C}$.

\subsubsection{3-Oxo-olean-12-ene-28-oic acid ethyl ester (OA-2)}

To a solution of OA-1 $(0.500 \mathrm{~g})$ in N,N-dimethylformamide (DMF), were added anhydrous $\mathrm{K}_{2} \mathrm{CO}_{3}(30 \mathrm{mg}, 0.22 \mathrm{mmol})$ and bromoethane $(0.24 \mathrm{~mL}, 5.02 \mathrm{mmol})$ at room temperature for $5 \mathrm{~h}$. The end of the reaction was detected by TLC. (developing solvent: petroleum ether/ethyl acetate $=5 / 1(\mathrm{~V} / \mathrm{V}))$. The crude product was purified by silica gel column chromatography (eluent: petroleum ether/ethyl acetate $=15 / 1(\mathrm{~V} / \mathrm{V})$ ) to give 
$0.324 \mathrm{~g}$ of white flaky solid OA-2, 57.9\%. m.p.189.4 191. ${ }^{\circ} \mathrm{C}$.

\subsubsection{2,3-Dioxo-olean-12-ene-28-oic acid ethyl ester (OA-3)}

The intermediate OA-2 $(0.300 \mathrm{~g})$ was dissolved in $10 \mathrm{~mL}$ tert-butanol(t-BuOH$)$ solution and reacted at $50{ }^{\circ} \mathrm{C}$. After completely dissolving, $0.15 \mathrm{~g}$ of potassium tertbutoxide was added and $1.5 \mathrm{~mL}$ of tetrahy-drofuran was added as catalyst. The end of the reaction was detected by TLC.(developing solvent: petroleum ether/ethyl acetate $=5 / 1(\mathrm{~V} / \mathrm{V})), 6 \mathrm{~h}$ reaction end. The organic layer was dried with anhydrous magnesium sulfate for $4 \mathrm{~h}$. The crude product was purified by silica gel column chromatography (eluent: petroleum ether/ethyl acetate $=15 / 1(\mathrm{~V} / \mathrm{V})$ ) to give $0.245 \mathrm{~g}$ of white flaky solid OA-3 in yield 80.24\%. m.p.187.7 187.2 ${ }^{\circ} \mathrm{C}$.

4.2.4. 5', 6'-dihydro-olean-2-ene-[2,3-b]pyrazin-12-ene-28-oic acid ethyl ester (OA-4)

OA-3 $(0.300 \mathrm{~g})$ was dissolved in $10 \mathrm{~mL}$ of absolute ethanol and $0.5 \mathrm{~g}$ of anhydrous magnesium sulfate was added.The supersaturated ethylenediamine-ethanol solution ( $0.04 \mathrm{~mL}$ ethylenediamine) was slowly added to the system, and the mixture was refluxed at $79{ }^{\circ} \mathrm{C}$ for $8 \mathrm{~h}$. The end of the reaction was detected by TLC.(developing solvent: petroleum ether/ethyl acetate $=5 / 1(\mathrm{~V} / \mathrm{V}))$, The crude product was purified by silica gel column chromatography (eluent: petroleum ether/ethyl acetate $=15 / 1(\mathrm{~V} / \mathrm{V})$ ) to give $0.186 \mathrm{~g}$ of a pale yellow oil, OA-4, in a yield of $72.30 \%$. m.p.201.1 203. $7^{\circ} \mathrm{C}$. 4.2.5 2-hydrazone-3-Oxo-olean-12-ene-28-oic acid ethyl ester $(\boldsymbol{O} \boldsymbol{A}-5)$.

OA-2 (0.300 g, $0.62 \mathrm{mmol})$ was dissolved in $30 \mathrm{~mL}$ of methanol. $1 \mathrm{~mL}$ of hydrazine hydrate was added and heated to reflux. The end of the reaction was detected by TLC.(developing solvent: petroleum ether/ethyl acetate $=3 / 1(\mathrm{~V} / \mathrm{V})$ ), $2 \mathrm{~h}$ reaction ends. The crude product was purified by silica gel column chromatography (eluent: petroleum ether/ethyl acetate $=15 / 1(\mathrm{~V} / \mathrm{V})$ ) to give $0.226 \mathrm{~g}$ of a yellow oil, OA-5, in a yield of $72.30 \%$. m.p.201.1 $203.7^{\circ} \mathrm{C}$.

\subsubsection{2-Oxo-olean-12-ene-28-acyl-aniline (OA-6)}

Take the intermediate OA-1 $(0.500 \mathrm{~g})$, add $25 \mathrm{~mL}$ of dry dichloromethane(DCM )and oxalyl chloride $(1.20 \mathrm{mmol})$ for $4 \mathrm{~h}$, the reaction solvent and unreacted oxalyl chloride were removed by steaming, and the residue was added with $10 \mathrm{~mL}$ of cyclohexane, followed by distillation of cyclohexane under reduced pressure and repeated operation three times. Acid chloride was added $15 \mathrm{~mL}$ DCM, and triethylamine adjusted to $\mathrm{pH} 9$ $\sim 10$, adding aniline $(2.2 \mathrm{mmol})$, room temperature reaction $6 \mathrm{~h}$, TLC detection reaction endpoint. The crude product was purified by silica gel column chromatography (eluent: petroleum ether/ethyl acetate $=20 / 1(\mathrm{~V} / \mathrm{V})$ ) to give the desired product. $0.396 \mathrm{~g}$ of pale yellow crystals of OA-6, yield\%. m.p.122.4 124. ${ }^{\circ} \mathrm{C}$.

\subsubsection{2,3-Dioxo-olean-12-ene-28-acyl-aniline( $\boldsymbol{O A}$-7)}

The intermediate OA-6(0.300g) was dissolved in $10 \mathrm{~mL}$ tert-butanol(t-BuOH) solution and reacted at $50{ }^{\circ} \mathrm{C}$. After completely dissolving, $0.15 \mathrm{~g}$ of potassium tertbutoxide was added and $1.5 \mathrm{~mL}$ of tetrahy-drofuran was added as catalyst. The end of the reaction was detected by TLC.(developing solvent: petroleum ether/ethyl acetate $=5 / 1(\mathrm{~V} / \mathrm{V})), 6 \mathrm{~h}$ reaction end.The organic layer was dried with anhydrous magnesium sulfate for $4 \mathrm{~h}$. The crude product was purified by silica gel column chromatography (eluent: petroleum ether / ethyl acetate $=15 / 1(\mathrm{~V} / \mathrm{V})$ ) to give $0.245 \mathrm{~g}$ of white flaky solid OA-3 in yield 81.67\%. m.p.192.1 194.3 ${ }^{\circ} \mathrm{C}$. 


\subsubsection{Olean-2-ene-[2,3-b] pyrazin-12-ene-28-oic acid ethyl ester $\left(\boldsymbol{I}_{1}\right)$}

The intermediate OA-4 $(0.500 \mathrm{~g})$ was dissolved in $20 \mathrm{~mL}$ of absolute ethanol, were added $\mathrm{KOH}(0.070 \mathrm{~g}, 1.00 \mathrm{mmol}), \mathrm{MnO}_{2}(0.260,3.00 \mathrm{~mol})$ and reflux. The end of the reaction was detected by TLC.(developing solvent: petroleum ether/ester = $5 / 1(\mathrm{~V} / \mathrm{V})), 6 \mathrm{~h}$ reaction ended. The crude product was purified by silica gel column chromatography (eluent: petroleum ether/ethyl acetate $=20 / 1(\mathrm{~V} / \mathrm{V})$ ) to give $0.370 \mathrm{~g}$ of a white powder as a solid in $73.5 \%$ yield. m.p.134.3 138. $1^{\circ} \mathrm{C}$.

$\left.{ }^{1} \mathrm{H}-\mathrm{NMR}\left(\mathrm{CDCl}_{3}, 300 \mathrm{MHz}\right) \delta: 8.41 \sim 8.27 （ \mathrm{~m}, 2 \mathrm{H}, \mathrm{NCHCHN}\right), 5.38 \sim 5.29(\mathrm{~m}, 1 \mathrm{H}, \mathrm{H}-$ 12), $2.50(\mathrm{t}, 1 \mathrm{H}), 4.12 \sim 4.05\left(\mathrm{~m}, 2 \mathrm{H}, \mathrm{COOC}_{2} \mathrm{CH}_{3}\right), 1.93\left(\mathrm{t}, J=7.0 \mathrm{~Hz}, 3 \mathrm{H}, \mathrm{COOCH}_{2} \mathrm{C}_{3}\right), 1.2$ $3(\mathrm{~s}, 3 \mathrm{H}), 1.18(\mathrm{~s}, J=7.6 \mathrm{~Hz}, 3 \mathrm{H}, \mathrm{H}-$ 18), 1.14(s,3H),1.12(s,3H), 1.02(s,3H),0.96(s,3H),0.95(s,3H), ESI-

$\mathrm{MS}(\mathrm{m} / \mathrm{z}): 518.3[\mathrm{M}+\mathrm{H}]^{+}$. Elemental anal.(\%) calcd. For $\mathrm{C}_{34} \mathrm{H}_{50} \mathrm{~N}_{2} \mathrm{O}_{2}: \mathrm{C} 78.72, \mathrm{H} 9.71, \mathrm{~N}$ 5.40,O 6.17;found: C 78.70,H 9.75,N 5.42,O 6.13.

4.2.9 Olean-2-ene-[2,3-b] pyrazin-12-ene-28-oic acid npropyl ester $\left(\mathbf{I}_{2}\right)$

According to the same method for compound $\mathrm{I}_{1}$, compound $\mathrm{I}_{2}$ was prepared from OA-1 $(1.1 \mathrm{mmol})$ and brominated npropane $(4.4 \mathrm{mmol})$, The crude product was purified by silica gel column chromatography (eluent: petroleum ether/ethyl acetate $=20 / 1(\mathrm{~V} / \mathrm{V})$ ) to give $0.330 \mathrm{~g}$ of a white powder as a solid in $72.4 \%$ yield. m.p.146.9 150.1 ${ }^{\circ} \mathrm{C}$.

${ }^{1} \mathrm{H}-\mathrm{NMR}\left(\mathrm{CDCl}_{3}, 300 \mathrm{MHz}\right) \delta: 8.40 \sim 8.24(\mathrm{~m}, 2 \mathrm{H}, \mathrm{NCHCHN}), 5.43 \sim 5.38(\mathrm{~m}, 1 \mathrm{H}, \mathrm{H}-$

12), $1.84(\mathrm{t}, 1 \mathrm{H} J=7.5 \mathrm{~Hz}, \mathrm{H}-$

18) $4.21\left(\mathrm{t}, 2 \mathrm{H}, J=7.5 \mathrm{~Hz}, \mathrm{COOC} \underline{\mathrm{H}}_{2} \mathrm{CH}_{2} \mathrm{CH}_{3}\right), 1.87\left(\mathrm{t}, 3 \mathrm{H}, J=11.7 \mathrm{~Hz}, \mathrm{COOCH}_{2} \underline{\mathrm{C}}_{3}\right)$, $1.32(\mathrm{~s}, 3 \mathrm{H}), 1.25(\mathrm{~s}, 3 \mathrm{H}), 1.13(\mathrm{~s}, 3 \mathrm{H}), 1.12(\mathrm{~s}, 3 \mathrm{H}), 1.02(\mathrm{~s}, 3 \mathrm{H}), 0.94(\mathrm{~s}, 3 \mathrm{H}), 0.83(\mathrm{~s}, 3 \mathrm{H})$, ESI-

$\mathrm{MS}(\mathrm{m} / \mathrm{z}): 532.4[\mathrm{M}+\mathrm{H}]^{+}$. Elemental anal.(\%) calcd. For $\mathrm{C}_{35} \mathrm{H}_{52} \mathrm{~N}_{2} \mathrm{O}_{2}: \mathrm{C} 78.90, \mathrm{H} 9.84, \mathrm{~N}$ 5.26,O 6.01;found: C 78.88,H 9.81,N 5.28,O 6.04.

\subsubsection{Olean-2-ene-[2,3-b] pyrazin-12-ene-28-oic acid nbutyl ester (I $\left.\boldsymbol{I}_{3}\right)$}

According to the same method for compound $\mathrm{I}_{1}$, compound $\mathrm{I}_{3}$ was prepared from OA-1 (1.1 mmol) and brominated nbutylane $(4.4 \mathrm{mmol})$, The crude product was purified by silica gel column chromatography (eluent: petroleum ether/ethyl acetate $=20 / 1(\mathrm{~V} / \mathrm{V})$ ) to give $0.362 \mathrm{~g}$ of a white powder as a solid in $73.5 \%$ yield. m.p.156.1 158.2 ${ }^{\circ} \mathrm{C}$.

$\left.{ }^{1} \mathrm{H}-\mathrm{NMR}\left(\mathrm{CDCl}_{3}, 300 \mathrm{MHz}\right) \delta: 8.24 \sim 8.36 （ \mathrm{~m}, 2 \mathrm{H}, \mathrm{NCHCHN}\right), 5.43 \sim 5.38(\mathrm{~m}, 1 \mathrm{H}, \mathrm{H}-$

12), $1.75(\mathrm{t}, J=7.3 \mathrm{~Hz}, 1 \mathrm{H}, \mathrm{H}-$

18), $4.04\left(\mathrm{t}, J=7.5 \mathrm{~Hz}, 2 \mathrm{H}, \mathrm{COOC} \underline{\mathrm{H}}_{2} \mathrm{CH}_{2} \mathrm{CH}_{2} \mathrm{CH}_{3}\right), 1.53(\mathrm{t}, 3 \mathrm{H}, J=10.3 \mathrm{~Hz}$, $\left.\mathrm{COOCH}_{2} \mathrm{CH}_{2} \mathrm{CH}_{2} \mathrm{CH}_{3}\right), 1.83 \sim 1.78\left(\mathrm{~m}, 4 \mathrm{H}, \mathrm{COOCH}_{2}\left(\mathrm{C}_{2}\right)_{2} \mathrm{CH}_{3}\right) .1 .44(\mathrm{~s}, 3 \mathrm{H}), 1.29(\mathrm{~s}, 3 \mathrm{H})$, $1.13(\mathrm{~s}, 3 \mathrm{H}), 1.12(\mathrm{~s}, 3 \mathrm{H}), 0.92(\mathrm{~s}, 3 \mathrm{H}), 0.83(\mathrm{~s}, 3 \mathrm{H}), 0.75(\mathrm{~s}, 3 \mathrm{H}), \operatorname{ESI}-\mathrm{MS}(\mathrm{m} / \mathrm{z}): 544.7[\mathrm{M}+\mathrm{H}]^{+}$. Elemental anal.(\%) calcd. For $\mathrm{C}_{36} \mathrm{H}_{54} \mathrm{~N}_{2} \mathrm{O}_{2}$ : C 79.07,H 9.95,N 5.12,O 5.85;found: C 79.03,H 9.99,N 5.10,O 5.87.

\subsubsection{Olean-2-ene-[2,3-b] pyrazin-12-ene-28-oic acid npentyl ester(I4)}

According to the same method for compound $\mathrm{I}_{1}$, compound $\mathrm{I}_{3}$ was prepared from OA-1 $(1.1 \mathrm{mmol})$ and brominated npentane $(4.4 \mathrm{mmol})$, The crude product was purified by silica gel column chromatography (eluent: petroleum ether/ethyl acetate $=20 / 1(\mathrm{~V} / \mathrm{V})$ ) to give $0.343 \mathrm{~g}$ of a white powder as a solid in $68.3 \%$ yield. m.p. $163.2 \sim 166.1^{\circ} \mathrm{C}$.

${ }^{1} \mathrm{H}-\mathrm{NMR}\left(\mathrm{CDCl}_{3}, 300 \mathrm{MHz}\right) \delta: 8.39 \sim 8.25 \quad(\mathrm{~m}, 2 \mathrm{H}, \mathrm{NCHCHN}), \quad 5.45 \sim 5.10(\mathrm{~m}, 1 \mathrm{H}, \mathrm{H}-$ 12), $2.50(\mathrm{t}, J=8.0 \mathrm{~Hz}, 1 \mathrm{H}, \mathrm{H}-18), 4.21\left(\mathrm{t}, J=7.5 \mathrm{~Hz}, 2 \mathrm{H}, \mathrm{COOC} \underline{H}_{2}\left(\mathrm{CH}_{2}\right)_{3} \mathrm{CH}_{3}\right), 1.87(\mathrm{t}, 3 \mathrm{H}$, $\left.J=12.3 \mathrm{~Hz}, \mathrm{COOCH}_{2}\left(\mathrm{CH}_{2}\right)_{3} \mathrm{CH}_{3}\right)$, 
1.67 1.42(m,6H,COOCH $\left.2\left(\mathrm{CH}_{2}\right)_{3} \mathrm{CH}_{3}\right) .1 .41(\mathrm{~s}, 3 \mathrm{H}), 1.32(\mathrm{~s}, 3 \mathrm{H}), 1.13(\mathrm{~s}, 3 \mathrm{H}), 1.03(\mathrm{~s}, 3 \mathrm{H}), 0$. 98(s,3H),0.86(s,3H),0.82(s,3H), ESI-MS $(m / z): 560.4[\mathrm{M}+\mathrm{H}]^{+}$. Elemental anal.(\%) calcd. For $\mathrm{C}_{37} \mathrm{H}_{56} \mathrm{~N}_{2} \mathrm{O}_{2}$ : C 79.24,H 10.06,N 4.99,O 5.71;found: C 79.26,H 10.09,N 4.97,O 5.68.

\subsubsection{Olean-2-ene-[2,3-b] pyrazin-12-ene-28-oic acid nhextyl ester $\left(\mathbf{I}_{5}\right)$}

According to the same method for compound $\mathrm{I}_{1}$, compound $\mathrm{I}_{3}$ was prepared from OA-1 $(1.1 \mathrm{mmol})$ and brominated nhexane $(4.4 \mathrm{mmol})$, The crude product was purified by silica gel column chromatography (eluent: petroleum ether/ethyl acetate $=20 / 1(\mathrm{~V} / \mathrm{V})$ ) to give $0.384 \mathrm{~g}$ of a white powder as a solid in $76.3 \%$ yield. m.p. $173.2 \sim 176.9^{\circ} \mathrm{C}$.

${ }^{1} \mathrm{H}-\mathrm{NMR}\left(\mathrm{CDCl}_{3}, 300 \mathrm{MHz}\right) \delta: 8.38 \sim 8.26(\mathrm{~m}, 2 \mathrm{H}, \mathrm{NCHCHN}), \quad 5.48 \sim 5.39(\mathrm{~m}, 1 \mathrm{H}, \mathrm{H}-$ 12), 1.74(t, $J=7.6 \mathrm{~Hz}, 1 \mathrm{H}, \mathrm{H}-18), 4.13\left(\mathrm{t}, J=7.0 \mathrm{~Hz}, 2 \mathrm{H}, \mathrm{COOC}_{2}\left(\mathrm{CH}_{2}\right)_{4} \mathrm{CH}_{3}\right), 1.53(\mathrm{t}$, $\left.J=12.5 \mathrm{~Hz}, 3 \mathrm{H}, \mathrm{COOCH}_{2}\left(\mathrm{CH}_{2}\right)_{4} \mathrm{CH}_{3}\right)$,

$2.05 \sim 1.81\left(\mathrm{~m}, 8 \mathrm{H}, \mathrm{COOCH}_{2}\left(\mathrm{CH}_{2}\right)_{4} \mathrm{CH}_{3}\right) .1 .47(\mathrm{~s}, 3 \mathrm{H}), 1.29(\mathrm{~s}, 3 \mathrm{H}), 1.25(\mathrm{~s}, 3 \mathrm{H}), 1.05(\mathrm{~s}, 3 \mathrm{H}), 0$. 99(s,3H),0.85(s,3H),0.79(s,3H), ESI-MS $(\mathrm{m} / \mathrm{z}): 574.3[\mathrm{M}+\mathrm{H}]^{+}$. Elemental anal.(\%) calcd. For $\mathrm{C}_{38} \mathrm{H}_{58} \mathrm{~N}_{2} \mathrm{O}_{2}$ : C 79.39, H 10.17, N 4.87,O 5.57;found: C 79.36, H 10.13,N 4.91,O 5.60.

3.2.13 5'-methyl-olean-2-ene- [2,3-b] pyrazine-12-ene-28-oic acid ethyl ester ( II $\left.{ }_{1}\right)$

The intermediate OA-3 $(0.500 \mathrm{~g})$ was dissolved in $20 \mathrm{~mL}$ of absolute ethanol and $0.5 \mathrm{~g}$ of anhydrous magnesium sulfate was added and the supersaturated 1,2propanediamine-ethanol solution $(0.04 \mathrm{~mL})$ was slowly added to the system, the mixture was stirred at $79^{\circ} \mathrm{C}$ for $8 \mathrm{~h}$. The solvent was removed by evaporation under reduced pressure. The crude product was purified by silica gel column chromatography (eluent: petroleum ether/ethyl acetate $=15 / 1(\mathrm{~V} / \mathrm{V})$ ) to give $0.389 \mathrm{~g}$ of a white powder as a yield of $73.5 \%$. m.p.156.3 158.1 ${ }^{\circ} \mathrm{C}$.

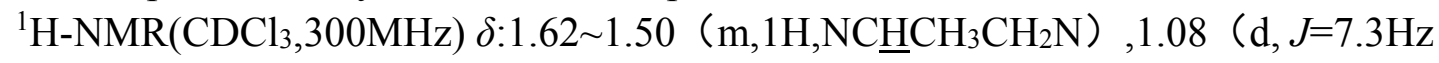
$\left.3 \mathrm{H}, \mathrm{NCHCH}_{3} \mathrm{CH}_{2} \mathrm{~N}\right), 1.41 \sim 1.23\left(\mathrm{~m}, 2 \mathrm{H}, \mathrm{NCHCH}_{3} \underline{\mathrm{C}}_{2} \mathrm{~N}\right), \quad 5.26 \sim 5.19(\mathrm{~m}, 1 \mathrm{H}, \mathrm{H}-$ 12), 2.65(t, $J=7.0 \mathrm{~Hz}, 1 \mathrm{H}, \mathrm{H}-18), 4.21 \sim 4.17\left(\mathrm{~m}, J=8.0 \mathrm{~Hz}, 2 \mathrm{H}, \mathrm{COOC}_{2} \mathrm{CH}_{3}\right), 1.21(\mathrm{t}$, $\left.J=10.4 \mathrm{~Hz}, 3 \mathrm{H}, \mathrm{COOCH}_{2} \mathrm{CH}_{3}\right)$, $1.23(\mathrm{~s}, 3 \mathrm{H}), 1.18(\mathrm{~s}, 3 \mathrm{H}), 1.14(\mathrm{~s}, 3 \mathrm{H}), 1.01(\mathrm{~s}, 3 \mathrm{H}), 0.99(\mathrm{~s}, 3 \mathrm{H}), 0.89(\mathrm{~s}, 3 \mathrm{H}), 0.87(\mathrm{~s}, 3 \mathrm{H})$, ESI$\mathrm{MS}(\mathrm{m} / z): 534.4[\mathrm{M}+\mathrm{H}]^{+}$. Elemental anal.(\%) calcd. For $\mathrm{C}_{35} \mathrm{H}_{54} \mathrm{~N}_{2} \mathrm{O}_{2}: \mathrm{C} 78.60, \mathrm{H}$ 10.18,N 5.24,O 5.98;found: C 78.62,H 10.15,N 5.27,O 5.96.

3.2.14 5'-methyl-olean-2-ene- [2,3-b] pyrazine-12-ene-28-oic acid npropyl ester( $\left.\mathrm{II}_{2}\right)$

According to the same method for compound $\mathrm{II}_{1}$, compound $\mathrm{II}_{2}$ was prepared from OA-1 (1.1mmol) and brominated npropane $(4.4 \mathrm{mmol})$, The crude product was purified by silica gel column chromatography (eluent: petroleum ether/ethyl acetate $=20 / 1(\mathrm{~V} / \mathrm{V})$ ) to give $0.283 \mathrm{~g}$ of a white powder as a solid in $40.31 \%$ yield. m.p.168.8 $171.3^{\circ} \mathrm{C}$.

$\left.{ }^{1} \mathrm{H}-\mathrm{NMR}\left(\mathrm{CDCl}_{3}, 300 \mathrm{MHz}\right) \delta: 1.63 \sim 1.55 （ \mathrm{~m}, 1 \mathrm{H}, \mathrm{NC}_{\underline{H C H}} \mathrm{CH}_{2} \mathrm{~N}\right), 1.12 （ \mathrm{~d}, J=7.8 \mathrm{~Hz}$, $\left.\left.3 \mathrm{H}, \mathrm{NCHC}_{3} \mathrm{CH}_{2} \mathrm{~N}\right), 1.42 \sim 1.21 （ \mathrm{~m}, 2 \mathrm{H}, \mathrm{NCHCH}_{3} \underline{\mathrm{H}}_{2} \mathrm{~N}\right), 5.26 \sim 5.19(\mathrm{~m}, 1 \mathrm{H}, \mathrm{H}-$ 12), 2.67(t,1H,H-18), 4.06(t, $\left.J=7.5 \mathrm{~Hz}, 2 \mathrm{H}, \mathrm{COOC}_{\mathrm{H}_{2}} \mathrm{CH}_{2} \mathrm{CH}_{3}\right), 1.01(\mathrm{t}, J=11.6 \mathrm{~Hz}$, $\left.3 \mathrm{H}, \mathrm{COOCH}_{2} \mathrm{CH}_{2} \mathrm{C}_{3}\right), 1.18(\mathrm{~s}, 3 \mathrm{H}), 1.16(\mathrm{~s}, 3 \mathrm{H}), 1.01(\mathrm{~s}, 3 \mathrm{H}), 1.01(\mathrm{~s}, 3 \mathrm{H}), 0.99(\mathrm{~s}, 3 \mathrm{H}), 0.94(\mathrm{~s}$ ,3H),0.89(s,3H), ESI-MS( $m / z): 548.4[\mathrm{M}+\mathrm{H}]^{+}$. Elemental anal.(\%) calcd. For $\mathrm{C}_{36} \mathrm{H}_{56} \mathrm{~N}_{2} \mathrm{O}_{2}$ : C 78.78,H 10.28,N 5.10,O 5.83;found: C 78.75,H 10.35,N 5.14,O 5.86. 3.2.15 5'-methyl-olean-2-ene- [2,3-b] pyrazine-12-ene-28-oic acid nbutyl ester ( $\mathrm{II}_{3}$ ) 
According to the same method for compound $\mathrm{II}_{1}$, compound $\mathrm{II}_{3}$ was prepared from OA-1 $(1.1 \mathrm{mmol})$ and brominated nbutylane $(4.4 \mathrm{mmol})$, The crude product was purified by silica gel column chromatography (eluent: petroleum ether/ethyl acetate $=20 / 1(\mathrm{~V} / \mathrm{V})$ ) to give $0.303 \mathrm{~g}$ of a white powder as a solid in $60.24 \%$ yield. m.p. $164.7 \sim 167.5^{\circ} \mathrm{C}$.

$\left.{ }^{1} \mathrm{H}-\mathrm{NMR}\left(\mathrm{CDCl}_{3}, 300 \mathrm{MHz}\right) \delta: 1.62 \sim 1.55 （ \mathrm{~m}, 1 \mathrm{H}, \mathrm{NC}_{\underline{H C H}} \mathrm{CH}_{2} \mathrm{~N}\right), 1.08 （ \mathrm{~d}, J=7.0 \mathrm{~Hz}$, $\left.\left.3 \mathrm{H}, \mathrm{NCHCH}{ }_{3} \mathrm{CH}_{2} \mathrm{~N}\right), 1.42 \sim 1.21 （ \mathrm{~m}, 2 \mathrm{H}, \mathrm{NCHCH}_{3} \underline{\mathrm{C}}_{2} \mathrm{~N}\right) \quad 5.24 \sim 5.18(\mathrm{~m}, 1 \mathrm{H}, \mathrm{H}-$ 12), 2.65(t, $J=7.5 \mathrm{~Hz}, 1 \mathrm{H}, \mathrm{H}-18), 4.10\left(\mathrm{t}, J=6.5 \mathrm{~Hz}, 2 \mathrm{H}, \mathrm{COOC} \underline{H}_{2}\left(\mathrm{CH}_{2}\right)_{2} \mathrm{CH}_{3}\right)$, $1.83 \sim 1.78\left(\mathrm{~m}, 4 \mathrm{H}, \mathrm{COOCH}_{2}\left(\mathrm{C}_{2}\right)_{2} \mathrm{CH}_{3}\right), \quad 1.01(\mathrm{t}, J=11.0 \mathrm{~Hz}$ $\left.3 \mathrm{H}, \mathrm{COOCH}_{2} \mathrm{CH}_{2} \mathrm{CH}_{2} \mathrm{CH}_{3}\right), 1.21(\mathrm{~s}, 3 \mathrm{H}), 1.17(\mathrm{~s}, 3 \mathrm{H}), 1.04(\mathrm{~s}, 3 \mathrm{H}), 1.03(\mathrm{~s}, 3 \mathrm{H}), 0.93(\mathrm{~s}, 3 \mathrm{H}), 0$. $89(\mathrm{~s}, 3 \mathrm{H}), 0.88(\mathrm{~s}, 3 \mathrm{H}), \mathrm{ESI}-\mathrm{MS}(\mathrm{m} / \mathrm{z}): 562.5[\mathrm{M}+\mathrm{H}]^{+}$. Elemental anal.(\%) calcd. For $\mathrm{C}_{37} \mathrm{H}_{58} \mathrm{~N}_{2} \mathrm{O}_{2}$ : C 78.95,H 10.39,N 4.98,O 5.68;found: C 78.98,H 10.35,N 5.00,O 5.67. 3.2.16 5'-methyl-olean-2-ene- [2,3-b] pyrazine-12-ene-28-oic acid npentyl ester ( $\left.\mathrm{II}_{4}\right)$

According to the same method for compound $\mathrm{II}_{1}$, compound $\mathrm{II}_{4}$ was prepared from OA-1 $(1.1 \mathrm{mmol})$ and brominated npentane $(4.4 \mathrm{mmol})$, The crude product was purified by silica gel column chromatography (eluent: petroleum ether/ethyl acetate $=20 / 1(\mathrm{~V} / \mathrm{V})$ ) to give $0.322 \mathrm{~g}$ of a white powder as a solid in $64.51 \%$ yield. m.p. $179.7 \sim 183.5^{\circ} \mathrm{C}$.

$\left.{ }^{1} \mathrm{H}-\mathrm{NMR}\left(\mathrm{CDCl}_{3}, 300 \mathrm{MHz}\right) \delta: 1.61 \sim 1.47 （ \mathrm{~m}, 1 \mathrm{H}, \mathrm{NCHCH}_{3} \mathrm{CH}_{2} \mathrm{~N}\right), 1.08 （ \mathrm{~d}, J=7.0 \mathrm{~Hz}$, $\left.\left.3 \mathrm{H}, \mathrm{NCHCH}_{3} \mathrm{CH}_{2} \mathrm{~N}\right), 1.42 \sim 1.21 （ \mathrm{~m}, 2 \mathrm{H}, \mathrm{NCHCH}_{3} \underline{\mathrm{C}}_{2} \mathrm{~N}\right) \quad 5.22 \sim 5.19(\mathrm{~m}, 1 \mathrm{H}, \mathrm{H}-$ 12), $2.61(\mathrm{t}, J=8.0 \mathrm{~Hz}, 1 \mathrm{H}, \mathrm{H}-18), 4.06\left(\mathrm{t}, J=6.5 \mathrm{~Hz}, 2 \mathrm{H}, \mathrm{COOC}_{2}\left(\mathrm{CH}_{2}\right)_{3} \mathrm{CH}_{3}\right)$, $1.68 \sim 1.39\left(\mathrm{~m}, 6 \mathrm{H}, \mathrm{COOCH}_{2}\left(\mathrm{C}_{2}\right)_{3} \mathrm{CH}_{3}\right), 1.01(\mathrm{t}$, $\left.J=12.5 \mathrm{~Hz}, 3 \mathrm{H}, \mathrm{COOCH}_{2}\left(\mathrm{CH}_{2}\right)_{3} \mathrm{C}_{3}\right), 1.23(\mathrm{~s}, 3 \mathrm{H}), 1.19(\mathrm{~s}, 3 \mathrm{H}), 1.04(\mathrm{~s}, 3 \mathrm{H}), 1.04(\mathrm{~s}, 3 \mathrm{H}), 0.97$ $(\mathrm{s}, 3 \mathrm{H}), 0.97(\mathrm{~s}, 3 \mathrm{H}), 0.87(\mathrm{~s}, 3 \mathrm{H}), \mathrm{ESI}-\mathrm{MS}(\mathrm{m} / \mathrm{z}): 576.5[\mathrm{M}+\mathrm{H}]^{+}$. Elemental anal.(\%) calcd. For $\mathrm{C}_{38} \mathrm{H}_{60} \mathrm{~N}_{2} \mathrm{O}_{2}$ : C 79.11,H 10.48,N 4.86,O 5.55;found: C 79.14,H 10.45,N 4.83,O 5.58 .

3.2.17 5'-methyl-olean-2-ene- [2,3-b] pyrazine-12-ene-28-oic acid nhextyl ester ( $\mathrm{II}_{5}$ )

According to the same method for compound $\mathrm{II}_{1}$, compound $\mathrm{II}_{4}$ was prepared from OA-1 (1.1 mmol) and brominated nhexane $(4.4 \mathrm{mmol})$, The crude product was purified by silica gel column chromatography (eluent:petroleum ether/ethyl acetate $=20 / 1(\mathrm{~V} / \mathrm{V}))$ to give $0.304 \mathrm{~g}$ of a white powder as a solid in $63.29 \%$ yield. m.p.196.2 199. $7^{\circ} \mathrm{C} .{ }^{1} \mathrm{H}-\mathrm{NMR}\left(\mathrm{CDCl}_{3}, 300 \mathrm{MHz}\right) \delta: 7.52$ （s,1H,NCHN）, $5.24 \sim 5.19(\mathrm{~m}, 1 \mathrm{H}, \mathrm{H}-12), 2.63(\mathrm{t}, J=8.0 \mathrm{~Hz}, 1 \mathrm{H}, \mathrm{H}-$

18), $4.22 \sim 4.02\left(\mathrm{~m}, 2 \mathrm{H}, \mathrm{COOC} \underline{H}_{2} \mathrm{CH}_{3}\right), 1.21\left(\mathrm{t}, J=10.5 \mathrm{~Hz}, 3 \mathrm{H}, \mathrm{COOCH}_{2} \underline{\mathrm{H}}_{3}\right), 1.18(\mathrm{~s}, 3 \mathrm{H}), 0$. $99(\mathrm{~s}, 3 \mathrm{H}), 0.99(\mathrm{~s}, 3 \mathrm{H}), 1.01(\mathrm{~s}, 3 \mathrm{H}), 0.99(\mathrm{~s}, 3 \mathrm{H}), 0.89(\mathrm{~s}, 3 \mathrm{H}), 0.89(\mathrm{~s}, 3 \mathrm{H})$, ESI-

$\mathrm{MS}(\mathrm{m} / z): 506.4[\mathrm{M}+\mathrm{H}]^{+}$. Elemental anal.(\%) calcd. For $\mathrm{C}_{39} \mathrm{H}_{62} \mathrm{~N}_{2} \mathrm{O}_{2}: \mathrm{C} 79.27, \mathrm{H}$ 10.58,N 4.74,O 5.41;found: C 79.30,H 10.55,N 4.75,O 5.40.

4.2.18 olean-2-ene- [2,3-b] imidazole-12-ene-28-oic acid ethyl ester (III)

A solution of intermediate OA-5 $(1.10 \mathrm{mmol})$ was dissolved in $20 \mathrm{~mL}$ of absolute ethanol, and formic acid $(1.10 \mathrm{mmol})$ was added and heated to reflux. $3 \mathrm{~h}$ latter, the product was poured into cold water and filtered. After drying, the crude product was purified by silica gel column chromatography (eluent: petroleum ether/ethyl acetate $=20 / 1(\mathrm{~V} / \mathrm{V})$ ) to give $0.204 \mathrm{~g}$ of white crystals $\mathrm{III}_{1}$ in $43.29 \%$ yield mp 196.2 199.7 ${ }^{\circ} \mathrm{C} .{ }^{1} \mathrm{H}-\mathrm{NMR}\left(\mathrm{CDCl}_{3}, 300 \mathrm{MHz}\right) \delta: 7.52$ (s,1H,NCHN) , 5.24 5.19(m,1H,H-12),2.63(t, $J=6.5 \mathrm{~Hz} 1 \mathrm{H}, \mathrm{H}-$ 18), $4.22 \sim 4.06\left(\mathrm{~m}, 2 \mathrm{H}, \mathrm{COOC} \underline{H}_{2} \mathrm{CH}_{3}\right), 1.21\left(\mathrm{t}, J=11.3 \mathrm{~Hz}, 3 \mathrm{H}, \mathrm{COOCH}_{2} \underline{\mathrm{C}}_{3}\right), 1.18(\mathrm{~s}, 3 \mathrm{H}), 0$. 
99(s,3H),0.99(s,3H),1.01(s,3H),0.99(s,3H),0.89(s,3H),0.89(s,3H), ESI-

$\mathrm{MS}(\mathrm{m} / \mathrm{z}): 506.4[\mathrm{M}+\mathrm{H}]^{+}$. Elemental anal.(\%) calcd. For $\mathrm{C}_{33} \mathrm{H}_{50} \mathrm{~N}_{2} \mathrm{O}_{2}$ : C 78.21,H 9.95,N 5.53,O 6.31;found: C 78.24,H 9.97,N 5.49,O 6.29.

4.2.19 olean-2-ene- [2,3-b] imidazole-12-ene-28-oic acid npropyl ester(III)

According to the same method for compound $\mathrm{III}_{1}$, compound $\mathrm{III}_{2}$ was prepared from OA-1 $(1.1 \mathrm{mmol})$ and brominated npropane $(4.4 \mathrm{mmol})$, The crude product was purified by silica gel column chromatography (eluent: petroleum ether/ethyl acetate $=20 / 1(\mathrm{~V} / \mathrm{V}))$ to give $0.192 \mathrm{~g}$ of a white powder as a solid in $40.15 \%$ yield. m.p.188.8 192.3 ${ }^{\circ} \mathrm{C} .{ }^{1} \mathrm{H}-\mathrm{NMR}\left(\mathrm{CDCl}_{3}, 300 \mathrm{MHz}\right) \delta: 7.56$ (s,1H,NCHN) , 5.24 5.15(m,1H,H-12),2.61(t, $J=7.2 \mathrm{~Hz}, 1 \mathrm{H}, \mathrm{H}-18), 4.06(\mathrm{t}$, $\left.J=8.0 \mathrm{~Hz}, 2 \mathrm{H}, \mathrm{COOC} \underline{H}_{2} \mathrm{CH}_{2} \mathrm{CH}_{3}\right), 1.01\left(\mathrm{t}, J=10.5 \mathrm{~Hz}, 3 \mathrm{H}, \mathrm{COOCH}_{2} \mathrm{CH}_{2} \mathrm{C}_{3} 3\right)$, $1.25(\mathrm{~s}, 3 \mathrm{H}), 1.18(\mathrm{~s}, 3 \mathrm{H}), 1.01(\mathrm{~s}, 3 \mathrm{H}), 1.01(\mathrm{~s}, 3 \mathrm{H}), 0.99(\mathrm{~s}, 3 \mathrm{H}), 0.87(\mathrm{~s}, 3 \mathrm{H}), 0.87(\mathrm{~s}, 3 \mathrm{H})$, ESI$\mathrm{MS}(\mathrm{m} / z): 520.4[\mathrm{M}+\mathrm{H}]^{+}$. Elemental anal.(\%) calcd. For $\mathrm{C}_{34} \mathrm{H}_{52} \mathrm{~N}_{2} \mathrm{O}_{2}: \mathrm{C} 78.41, \mathrm{H}$ 10.06,N 5.38,O 6.14;found: C 78.38,H 10.08,N 5.41,O 6.11. 4.2.20 olean-2-ene- [2,3-b] imidazole-12-ene-28-oic acid nbutyl ester ( $\left.\mathrm{II}_{3}\right)$

According to the same method for compound $\mathrm{III}_{1}$, compound $\mathrm{III}_{3}$ was prepared from OA-1 (1.1 mmol) and brominated nbutylane $(4.4 \mathrm{mmol})$, The crude product was purified by silica gel column chromatography (eluent: petroleum ether/ethyl acetate $=20 / 1(\mathrm{~V} / \mathrm{V}))$ to give $0.231 \mathrm{~g}$ of a white powder as a solid in $45.35 \%$ yield. m.p. $176.3 \sim 180.1^{\circ} \mathrm{C} .{ }^{1} \mathrm{H}-\mathrm{NMR}\left(\mathrm{CDCl}_{3}, 300 \mathrm{MHz}\right) \delta: 7.61$ （s,1H,NCHN）, 5.24 5.19(m,1H,H-12),2.66(t, $J=7.5 \mathrm{~Hz}, 1 \mathrm{H}, \mathrm{H}-18), 4.08(\mathrm{t}, 2 \mathrm{H}$, $\left.J=7.0 \mathrm{~Hz}, \mathrm{COOC}_{2}\left(\mathrm{CH}_{2}\right)_{2} \mathrm{CH}_{3}\right), 1.54 \sim 1.40\left(\mathrm{~m}, 4 \mathrm{H}, \mathrm{COOCH}_{2}\left(\mathrm{C}_{2}\right)_{2} \mathrm{CH}_{3}\right), \quad 0.90(\mathrm{t}$, $\left.J=12.5 \mathrm{~Hz}, 3 \mathrm{H}, \mathrm{COOCH}_{2}\left(\mathrm{CH}_{2}\right)_{2} \mathrm{C}_{3}\right), 1.31(\mathrm{~s}, 3 \mathrm{H}), 1.27(\mathrm{~s}, 3 \mathrm{H}), 1.21(\mathrm{~s}, 3 \mathrm{H})$, 1.18(s,3H), 1.01(s,3H), 1.01(s,3H),0.99(s,3H),ESI-MS( $m / z): 534.4[\mathrm{M}+\mathrm{H}]^{+}$. Elemental anal.(\%) calcd. For $\mathrm{C}_{35} \mathrm{H}_{54} \mathrm{~N}_{2} \mathrm{O}_{2}$ : C 78.60,H 10.18,N 5.24,O 5.98;found: C 78.63,H 10.20,N 5.20,O 5.97.

4.2.21 olean-2-ene- [2,3-b] imidazole-12-ene-28-oic acid npentyl ester(III)

According to the same method for compound $\mathrm{III}_{1}$, compound $\mathrm{III}_{3}$ was prepared from OA-1 (1.1 mmol) and brominated nbutylane $(4.4 \mathrm{mmol})$, The crude product was purified by silica gel column chromatography (eluent: petroleum ether/ethyl acetate $=20 / 1(\mathrm{~V} / \mathrm{V}))$ to give $0.153 \mathrm{~g}$ of a white powder as a solid in $37.23 \%$ yield. m.p.182.3 185.8 ${ }^{\circ} \mathrm{C} .{ }^{1} \mathrm{H}-\mathrm{NMR}\left(\mathrm{CDCl}_{3}, 300 \mathrm{MHz}\right) \delta: 7.60$ (s,1H,NCHN), $5.24 \sim 5.19(\mathrm{~m}, 1 \mathrm{H}, \mathrm{H}-12), 2.62(\mathrm{t}, J=7.5 \mathrm{~Hz}, 1 \mathrm{H}, \mathrm{H}-18), 4.04(\mathrm{t}, 2 \mathrm{H}, J=8.5 \mathrm{~Hz}$, $\left.\mathrm{COOC}_{2}\left(\mathrm{CH}_{2}\right)_{3} \mathrm{CH}_{3}\right), 1.60 \sim 1.39\left(\mathrm{~m}, 6 \mathrm{H}, \mathrm{COOCH}_{2}\left(\mathrm{CH}_{2}\right)_{3} \mathrm{CH}_{3}\right), \quad 0.90(\mathrm{t}, J=11.5 \mathrm{~Hz}$ $\left.3 \mathrm{H}, \mathrm{COOCH}_{2}\left(\mathrm{CH}_{2}\right)_{3} \mathrm{CH}_{3}\right), 1.27(\mathrm{~s}, 3 \mathrm{H}), 1.27(\mathrm{~s}, 3 \mathrm{H}), 1.19(\mathrm{~s}, 3 \mathrm{H}), 1.18(\mathrm{~s}, 3 \mathrm{H}), 1.01(\mathrm{~s}, 3 \mathrm{H})$, 0.99(s,3H),0.99(s,3H),ESI-MS $(m / z): 548.4[\mathrm{M}+\mathrm{H}]^{+}$. Elemental anal.(\%) calcd. For $\mathrm{C}_{36} \mathrm{H}_{56} \mathrm{~N}_{2} \mathrm{O}_{2}$ : C 78.78,H 10.28,N 5.10,O 5.83;found: C 78.75,H 10.31,N 5.12,O 5.81. 4.2.22 olean-2-ene- [2,3-b] imidazole-12-ene-28-oic acid nhextyl ester( II $_{5}$ )

According to the same method for compound $\mathrm{II}_{1}$, compound $\mathrm{II}_{4}$ was prepared from OA-1 (1.1mmol) and brominated nhexane $(4.4 \mathrm{mmol})$, The crude product was purified by silica gel column chromatography (eluent:petroleum ether/ethyl acetate $=20 / 1(\mathrm{~V} / \mathrm{V}))$ to give $0.273 \mathrm{~g}$ of a white powder as a solid in $51.26 \%$ yield. m.p.189.2 193.4 ${ }^{\circ} \mathrm{C} .{ }^{1} \mathrm{H}-\mathrm{NMR}\left(\mathrm{CDCl}_{3}, 300 \mathrm{MHz}\right) \delta: 7.64$ (s,1H,NCHN), $5.23 \sim 5.20(\mathrm{~m}, 1 \mathrm{H}, \mathrm{H}-12), 2.66(\mathrm{t}, J=6.5 \mathrm{~Hz}, 1 \mathrm{H}, \mathrm{H}-18), 4.06(\mathrm{t}, J=7.5 \mathrm{~Hz}$ 
$\left.2 \mathrm{H}, \mathrm{COOC}_{2}\left(\mathrm{CH}_{2}\right)_{4} \mathrm{CH}_{3}\right), 1.60 \sim 1.37\left(\mathrm{~m}, 8 \mathrm{H}, \mathrm{COOCH}_{2}\left(\mathrm{C}_{2}\right)_{4} \mathrm{CH}_{3}\right), \quad 0.83(\mathrm{t}$, $\left.J=10.7 \mathrm{~Hz}, 3 \mathrm{H}, \mathrm{COOCH}_{2}\left(\mathrm{CH}_{2}\right)_{4} \mathrm{CH}_{3}\right), \quad 1.32(\mathrm{~s}, 3 \mathrm{H}), 1.25(\mathrm{~s}, 3 \mathrm{H}), 1.13(\mathrm{~s}, 3 \mathrm{H})$, $1.12(\mathrm{~s}, 3 \mathrm{H}), 1.02(\mathrm{~s}, 3 \mathrm{H}), 0.94(\mathrm{~s}, 3 \mathrm{H}), 0.83(\mathrm{~s}, 3 \mathrm{H}), \mathrm{ESI}-\mathrm{MS}(\mathrm{m} / \mathrm{z}): 562.4[\mathrm{M}+\mathrm{H}]^{+}$. Elemental anal.(\%) calcd. For $\mathrm{C}_{37} \mathrm{H}_{58} \mathrm{~N}_{2} \mathrm{O}_{2}$ : C 78.95,H 10.39,N 4.98,O 5.68;found: C 78.97,H $10.37, \mathrm{~N} 5.01, \mathrm{O} 5.65$.

4.2.23 5'-methyl-olean-2-ene- [2,3-b] pyrazine-12-ene-28-acylanilide $\left(I_{1}\right)$

The intermediate OA-7 $(0.500 \mathrm{~g})$ was dissolved in $20 \mathrm{~mL}$ of absolute ethanol and $0.5 \mathrm{~g}$ of anhydrous magnesium sulfate was added and the supersaturated 1,2propanediamine-ethanol solution $(0.04 \mathrm{~mL})$ was slowly added to the system, the mixture was stirred at $79^{\circ} \mathrm{C}$ for $8 \mathrm{~h}$. The solvent was removed by evaporation under reduced pressure. The crude product was purified by silica gel column chromatography (eluent: petroleum ether/ethyl acetate $=15 / 1(\mathrm{~V} / \mathrm{V})$ ) to give $0.235 \mathrm{~g}$ of a white powder as a yield of $75.32 \%$. m.p.193.1.3 196.4 ${ }^{\circ} \mathrm{C}$.

$\left.{ }^{1} \mathrm{H}-\mathrm{NMR}\left(\mathrm{CDCl}_{3}, 300 \mathrm{MHz}\right) \delta: 1.62 \sim 1.49 （ \mathrm{~m}, 1 \mathrm{H}, \mathrm{NC}_{\underline{H}} \mathrm{H}_{3} \mathrm{CH}_{2} \mathrm{~N}\right), 1.07 （ \mathrm{~d}$, $\left.J=6.5 \mathrm{~Hz}, 3 \mathrm{H}, \mathrm{NCHC}_{3} \mathrm{CH}_{2} \mathrm{~N}\right), 1.43 \sim 1.25\left(\mathrm{~m}, 2 \mathrm{H}, \mathrm{NCHCH}_{3} \mathrm{CH}_{2} \mathrm{~N}\right) \quad 5.20(\mathrm{~s}, 1 \mathrm{H}, \mathrm{H}-$ 12), 2.22 (t, J=7.2Hz,1H, H-18), 7.26 7.09 (m, 1H, CONHC $\left.6 \mathrm{H}_{5}\right), 7.21 \sim 7.63(\mathrm{~m}, 5 \mathrm{H}$, $\left.\mathrm{CONHC}_{6} \mathrm{H}_{5}\right), 1.25$ (s, 3H), $1.18(\mathrm{~s}, 3 \mathrm{H}), 1.02(\mathrm{~s}, 3 \mathrm{H}), 0.95$ (s, 3H), $0.96(\mathrm{~s}, 3 \mathrm{H}), 0.87$ $(\mathrm{s}, 3 \mathrm{H}), 0.73(\mathrm{~s}, 3 \mathrm{H}), \mathrm{ESI}-\mathrm{MS}(\mathrm{m} / \mathrm{z}): 581.4[\mathrm{M}+\mathrm{H}]^{+}$. Elemental anal.(\%) calcd. For $\mathrm{C}_{39} \mathrm{H}_{55} \mathrm{~N}_{3} \mathrm{O}$ : C 80.50,H 9.53,N 7.22,O 2.75;found: C 80.52,H 9.51,N 7.21,O 2.76. 4.2.24 5'-methyl-olean-2-ene- [2,3-b] pyrazine-12-ene-28-acylchloroaniline $\left(\mathrm{IV}_{2}\right)$

According to the same method for compound $\mathrm{IV}_{1}$, compound $\mathrm{IV}_{4}$ was prepared from OA-1 (1.1 mmol) and m-chloroaniline $(2.2 \mathrm{mmol})$, The crude product was purified by silica gel column chromatography (eluent:petroleum ether/ethyl acetate $=13 / 1(\mathrm{~V} / \mathrm{V}))$ to give $0.235 \mathrm{~g}$ of a white powder as a solid in $75.32 \%$ yield. m.p.193.1 196. ${ }^{\circ} \mathrm{C}$.

$\left.{ }^{1} \mathrm{H}-\mathrm{NMR}\left(\mathrm{CDCl}_{3}, 300 \mathrm{MHz}\right) \delta: 1.62 \sim 1.52 （ \mathrm{~m}, 1 \mathrm{H}, \mathrm{NCHCH}_{3} \mathrm{CH}_{2} \mathrm{~N}\right), 1.07 （ \mathrm{~d}$, $\left.J=6.2 \mathrm{~Hz}, 3 \mathrm{H}, \mathrm{NCHC}_{3} \mathrm{CH}_{2} \mathrm{~N}\right), 1.43 \sim 1.25\left(\mathrm{~m}, 2 \mathrm{H}, \mathrm{NCHCH}_{3} \mathrm{C}_{2} \mathrm{~N}\right) 5.20$ (s, $1 \mathrm{H}, \mathrm{H}-$ 12), 2.22 (t, $J=7.5 \mathrm{~Hz}, 1 \mathrm{H}, \mathrm{H}-18), 7.26\left(\mathrm{~m}, 1 \mathrm{H}, \mathrm{CONHC}_{6} \mathrm{H}_{5}\right), 7.63 \sim 7.21(\mathrm{~m}, 5 \mathrm{H}$, $\left.\mathrm{CONHC}_{6} \mathrm{H}_{5}\right), 1.25(\mathrm{~s}, 3 \mathrm{H}), 1.18(\mathrm{~s}, 3 \mathrm{H}), 1.02(\mathrm{~s}, 3 \mathrm{H}), 0.95(\mathrm{~s}, 3 \mathrm{H}), 0.96(\mathrm{~s}, 3 \mathrm{H}), 0.87$ $(\mathrm{s}, 3 \mathrm{H}), 0.73(\mathrm{~s}, 3 \mathrm{H})$, ESI-MS $(\mathrm{m} / \mathrm{z}): 581.4[\mathrm{M}+\mathrm{H}]^{+}$. Elemental anal.(\%) calcd. For $\mathrm{C}_{39} \mathrm{H}_{54} \mathrm{ClN}_{3} \mathrm{O}: \mathrm{C} 76.00, \mathrm{H} 8.83, \mathrm{Cl} 5.75, \mathrm{~N}$ 6.82,O 2.60;found: $\mathrm{C} 76.04, \mathrm{H} 8.80, \mathrm{Cl}$ $5.77, \mathrm{~N} 6.80, \mathrm{O} 2.59$.

4.2.25 5'-methyl-olean-2-ene- [2,3-b] pyrazine-12-ene-28-acylfluaniline( $\left.I_{3}\right)$

According to the same method for compound $\mathrm{IV}_{1}$, compound $\mathrm{IV}_{4}$ was prepared from OA-1 (1.1mmol) and m-fluoroaniline $(2.2 \mathrm{mmol})$, The crude product was purified by silica gel column chromatography (eluent:petroleum ether/ethyl acetate $=13 / 1(\mathrm{~V} / \mathrm{V}))$ to give $0.235 \mathrm{~g}$ of a white powder as a solid in $58.32 \%$ yield. m.p.213.5 215.6 $6^{\circ} \mathrm{C}$.

$\left.{ }^{1} \mathrm{H}-\mathrm{NMR}\left(\mathrm{CDCl}_{3}, 300 \mathrm{MHz}\right) \delta: 1.63 \sim 1.52 （ \mathrm{~m}, 1 \mathrm{H}, \mathrm{NCHCH}_{3} \mathrm{CH}_{2} \mathrm{~N}\right), 1.10 （ \mathrm{~d}$, $\left.\left.J=6.5 \mathrm{~Hz}, 3 \mathrm{H}, \mathrm{NCHCH}_{3} \mathrm{CH}_{2} \mathrm{~N}\right), 1.39 \sim 1.25 （ \mathrm{~m}, 2 \mathrm{H}, \mathrm{NCHCH}_{3} \underline{\mathrm{C}}_{2} \mathrm{~N}\right) \quad 5.27(\mathrm{~s}, 1 \mathrm{H}, \mathrm{H}-$ 12), 2.26(t, J=7.3Hz,1H, H-18), 7.25 (s, 1H, $\left.\mathrm{CONHC}_{6} \mathrm{H}_{4} \mathrm{~F}\right), 7.98 \sim 7.23$ (m, 4H, $\left.\mathrm{CONHC}_{6} \mathrm{H}_{4} \mathrm{~F}\right), 1.25(\mathrm{~s}, 3 \mathrm{H}), 1.17(\mathrm{~s}, 3 \mathrm{H}), 1.02(\mathrm{~s}, 3 \mathrm{H}), 0.97(\mathrm{~s}, 3 \mathrm{H}), 0.96(\mathrm{~s}, 3 \mathrm{H}), 0.81$ $(\mathrm{s}, 3 \mathrm{H}), 0.75(\mathrm{~s}, 3 \mathrm{H})$, ESI-MS $(\mathrm{m} / \mathrm{z}): 599.4[\mathrm{M}+\mathrm{H}]^{+}$. Elemental anal.(\%) calcd. For $\mathrm{C}_{39} \mathrm{H}_{54} \mathrm{FN}_{3} \mathrm{O}$ : C 78.09,H 9.07, F 3.17,N 7.00,O 2.67;found: C 78.06,H 9.10, F 3.18,N 


\subsection{2,O 2.64 .}

\subsubsection{5'-methyl-olean-2-ene- [2,3-b] pyrazine-12-ene-28-acofluoroaniline $\left(I_{4}\right)$}

According to the same method for compound $\mathrm{IV}_{1}$, compound $\mathrm{IV}_{4}$ was prepared from OA-1 (1.1mmol) and m-fluoroaniline $(2.2 \mathrm{mmol})$, The crude product was purified by silica gel column chromatography (eluent:petroleum ether/ethyl acetate $=15 / 1(\mathrm{~V} / \mathrm{V}))$ to give $0.523 \mathrm{~g}$ of a white powder as a solid in $62.54 \%$ yield. m.p.208.9 211. $6^{\circ} \mathrm{C}$.

$\left.{ }^{1} \mathrm{H}-\mathrm{NMR}\left(\mathrm{CDCl}_{3}, 300 \mathrm{MHz}\right) \delta: 1.67 \sim 1.44 （ \mathrm{~m}, 1 \mathrm{H}, \mathrm{NCHCH}_{3} \mathrm{CH}_{2} \mathrm{~N}\right), 1.08 （ \mathrm{~d}$, $\left.J=6.5 \mathrm{~Hz}, 3 \mathrm{H}, \mathrm{NCHC}_{3} \mathrm{CH}_{2} \mathrm{~N}\right), 1.43 \sim 1.30\left(\mathrm{~m}, 2 \mathrm{H}, \mathrm{NCHCH}_{3} \mathrm{CH}_{2} \mathrm{~N}\right) 5.22(\mathrm{~s}, 1 \mathrm{H}, \mathrm{H}-$ 12), 2.25(t, $J=7.5 \mathrm{~Hz}, 1 \mathrm{H}, \mathrm{H}-18), 7.25\left(\mathrm{~s}, 1 \mathrm{H}, \mathrm{CON}^{\mathrm{HC}}{ }_{6} \mathrm{H}_{4} \mathrm{OCH}_{3}\right), 7.22 \sim 7.07$ (m, 4H, $\left.\mathrm{CONHC}_{6} \underline{\mathrm{H}}_{4} \mathrm{OCH}_{3}\right), 4.05\left(\mathrm{~s}, 3 \mathrm{H}, \mathrm{CONHC}_{6} \mathrm{H}_{4} \mathrm{OCH}_{3}\right), 1.23(\mathrm{~s}, 3 \mathrm{H}), 1.18(\mathrm{~s}, 3 \mathrm{H}), 1.09(\mathrm{~s}$, $3 \mathrm{H}), 0.95(\mathrm{~s}, 3 \mathrm{H}), 0.94(\mathrm{~s}, 3 \mathrm{H}), 0.83(\mathrm{~s}, 3 \mathrm{H}), 0.78(\mathrm{~s}, 3 \mathrm{H}), \operatorname{ESI}-\mathrm{MS}(\mathrm{m} / \mathrm{z}): 611.4[\mathrm{M}+\mathrm{H}]^{+}$. Elemental anal.(\%) calcd. For $\mathrm{C}_{40} \mathrm{H}_{57} \mathrm{~N}_{3} \mathrm{O}_{2}$ : C 78.51,H 9.39,N 6.87,O 5.23;found: C 78.48,H 9.42,N 6.88,O 5.22.

4.2.27 5'-methyl-olean-2-ene- [2,3-b] pyrazine-12-ene-28-morphomorpholine $\left(I_{5}\right)$

According to the same method for compound $\mathrm{IV}_{1}$, compound $\mathrm{IV}_{4}$ was prepared from OA-1 $(1.1 \mathrm{mmol})$ and methoxy aniline $(2.2 \mathrm{mmol})$, The crude product was purified by silica gel column chromatography (eluent:petroleum ether/ethyl acetate $=15 / 1(\mathrm{~V} / \mathrm{V}))$ to give $0.402 \mathrm{~g}$ of a white powder as a solid in $55.34 \%$ yield. m.p.221.6 225.3 ${ }^{\circ} \mathrm{C}$.

$\left.{ }^{1} \mathrm{H}-\mathrm{NMR}\left(\mathrm{CDCl}_{3}, 300 \mathrm{MHz}\right) \delta: 1.67 \sim 1.51 （ \mathrm{~m}, 1 \mathrm{H}, \mathrm{NCHCH}_{3} \mathrm{CH}_{2} \mathrm{~N}\right), 1.08 （ \mathrm{~d}$, $\left.J=6.5 \mathrm{~Hz}, 3 \mathrm{H}, \mathrm{NCHC}_{3} \mathrm{CH}_{2} \mathrm{~N}\right), 1.43 \sim 1.30\left(\mathrm{~m}, 2 \mathrm{H}, \mathrm{NCHCH}_{3} \mathrm{C}_{2} \mathrm{~N}\right) 5.22(\mathrm{~s}, 1 \mathrm{H}, \mathrm{H}-$ 12), $2.40(\mathrm{t}, J=7.0 \mathrm{~Hz}, 1 \mathrm{H}, \mathrm{H}-18), 3.38 \sim 3.30\left(\mathrm{~m}, 4 \mathrm{H}, \mathrm{N}\left(\mathrm{C}_{2}\right)_{2}\left(\mathrm{CH}_{2}\right)_{2} \mathrm{O}\right), 3.62-3.52$ (m, $\left.4 \mathrm{H}, \mathrm{N}\left(\mathrm{CH}_{2}\right)_{2}\left(\mathrm{CH}_{2}\right)_{2} \mathrm{O}\right), 1.44(\mathrm{~s}, 3 \mathrm{H}), 1.26(\mathrm{~s}, 3 \mathrm{H}), 1.21(\mathrm{~s}, 3 \mathrm{H}), 0.95(\mathrm{~s}, 3 \mathrm{H}), 0.94(\mathrm{~s}, 3 \mathrm{H})$, 0.85(s, 3H), 0.79(s, 3H), ESI-MS $(m / z): 575.4[\mathrm{M}+\mathrm{H}]^{+}$. Elemental anal.(\%) calcd. For $\mathrm{C}_{37} \mathrm{H}_{57} \mathrm{~N}_{3} \mathrm{O}_{2}$ : C 77.17,H 9.98,N 7.30,O 5.56;found: C 77.20,H 9.95,N 7.27,O 5.59.

\subsection{Cell Proliferative Assay}

The antiproliferative activities of the title compounds were evaluated in vitro using the MTT method against SKOV3 and BGC-823 cell lines, with 5-FU and Adriamycin as the positive control. The negative control contains cells, culture medium, MTT and DMSO. The two tumor cell lines were cultured in RPMI 1640 medium supplemented with $10 \%$ fetal bovine serum (FBS). Tumor cells were detached by trypsinisation, seeded at $1.0 \sim 2.0 \times 10^{3}$ cells each well in 96-well culture plates and incubated in $5 \% \mathrm{CO}_{2}$ at $37^{\circ} \mathrm{C}$. After $24 \mathrm{~h}$, the test compounds was added at different indicated concentration of $10^{-5}, 10^{-6}, 10^{-7}$, and $10^{-8} \mathrm{~mol} / \mathrm{L}$ for another $48 \mathrm{~h}$ incubation. Then MTT solution $\left(100 \mu \mathrm{L}\right.$ per well) was added and incubated at $37^{\circ} \mathrm{C}$ for $4 \mathrm{~h}$. The MTT-formazan formed by metabolically viable cells was dissolved in $150 \mu \mathrm{L}$ DMSO each well, and monitored by a microplate reader at dual-wavelength of $490 \mathrm{~nm}, \mathrm{IC}_{50}$ was defined as the drug concentrations that inhibited the cell number to $50 \%$ after $48 \mathrm{~h}$. Each experiment was repeated at least three times and the results averaged.

\section{Acknowledgements}

This work was financially supported by the Natural Science Foundation of Liaoning Province (NO.201605288), 


\section{References}

1. Li,Y.;L;F,W.;Chen,H.Y.;Deng,X.J.;Wei,Z.Q.;Wu,Q.K.; Xi,Y.L. Study on Pharmacological Action of Oleanolic Acid. Biotechworld.2015, (4): 125 127.

2. Wan,X.L.;Xie,X.L.;Liu,J.;Lu,F.Y. Hepatoprotective effect of oleanolic acid on Dgalactosamine-induced acute liver injury in the mice. $W C J \cdot P S, \mathbf{2 0 1 6}, 31(1)$ : 26 29.

3. Wu,L.L.;Zhou,E.X.;Zhao,R.D.;Han,X.;Yun,F.Y.Liu,B.C.;Yun,S.;A Survey of Oleanolic Acid in Malignant Tumors.Translational Medicine Journal, 2015, (2): $115 \sim 117$.

4. Zhang,M.F.;Shen,Y.Q. Research Advances in Pharmacological Effects of Oleanolic Acid in Hypoglycemia andAntidiabetic Complications. Anti Infect Pharm, 2015, 12(6): 801 806.

5. Huang, D.; Ding, Y.; Li, Y.; Zhang, W.; Fang, W. M.; Chen, X.G. Anti-tumor acitivity of a 3-oxo derivative of oleanolic acid.Cancer Lett. 2006, 233,2, P. 289

6. Meng,Y.Q.;Feng,C.Q.;Zhang,L.F.;Zhang,M.;Zhao,N. Synthesis and Anti-tumor Activity of Oleanolic Acid Derivatives. Acta Pharma Sincia. 2015, 50,4. 469-474.

7. Meng,Y.Q.;Zhang, L.F. Synthesis and antitumor activity evaluation of novel ursolic acid derivatives. Journal of Asian Natural Products Research,2016,18(3):280 288

8. Meng,Y.Q.; Liu,D.; Bai,Z.W.; Cai,L.L.; Ai, H.R. Synthesis and Anti-tumor Activity of Ursolic Acid Derivatives. Acta Pharm Sin.2011, 46, 5. 556-560

9. Meng,Y.Q.; Cao, J.; Tang, Y.; Lu, X. Y.; Liu, L. W. Synthesis and Anti-tumor Activity of Derivatives of Ring A of Ursolic Acid.Chinese.Chin. J. Org. Chem.2016, 36.1080-1087.

10. Meng,Y.Q.;Zhao,Y.W.; Zhenyu Kuai.;Liwei Liu.;Wei Li.Synthesis of Oleanolic acid A ring combined with heterocyclic ring derivatives. Journal of Asian Natural Products Research.2017.

11. Meng,Y.Q.;Xing,W.;Kuai,Z.Y.;Zhang,W.C.;Li,W. Synthesis and Anti-Tumor Activities of Ring A derived Analogues of Oleanolic Acid. Chin. J. Org. Chem.2017

12. Mohane Selvaraj C;Fang-Ying T;Jagat Rakesh K; et al. Treat cancers by targeting survivin: just a dream or future reality?Cancer Treatment Reviews, 2013,39(7):802-811.

13. Jianteng W;Haizhou L;Ming L;et al. Oleanolic acid potentiates the antitumor activity of 5-fluorouracil in pancreatic cancer cells. Oncology Reports,2012,28(4):1339-1345.

14. Kelly Araújo L; Rocha,G.D.G;Leonardo Campos M R;et al. Oleanolic Acid Initiates Apoptosis in Non-Small Cell Lung Cancer Cell Lines and Reduces Metastasis of a B16F10 Melanoma Model In Vivo. Plos One,2011,6(12):65-65.

15. Marzia Pennati;Stefania Sbarra;Cesare,M.D;et al. YM155 sensitizes triple-negative breast cancer to membrane-bound TRAIL through p38 MAPK-and CHOPmediated DR5 upregulation. International Journal of Cancer,2015,36(2):299-309. 
16. Kudchadkar R;Ernst S; Chmielowski B; et al. A phase 2, multicenter, open-label study of sepantronium bromide (YM155) plus docetaxel in patients with stage III (unresectable) or stage IV melanoma. Cancer Medicine,2015,4(5):643-650.

17. $\mathrm{Xu}, \mathrm{S}$;Adisetiyo, $\mathrm{H}$; Tamura, $\mathrm{S}$; et al.Dual inhibition of survivin and MAOA synergistically impairs growth of PTEN-negative prostate cancer. British Journal of Cancer,2015,113(2):1-10. 